\title{
Novel Diagnostic and Therapeutic Strategies in Juvenile Autoimmune Hepatitis
}

\author{
Marco Sciveres $^{1}$, Silvia Nastasio ${ }^{2}$ and Giuseppe Maggiore ${ }^{1,3 *}$ \\ ${ }^{1}$ Pediatric Hepatology and Liver Transplantation, ISMETT-University of Pittsburgh Medical Center Italy, Palermo, Italy, \\ ${ }^{2}$ Division of Gastroenterology, Hepatology, and Nutrition, Harvard Medical School, Boston Children's Hospital, Boston, MA, \\ United States, ${ }^{3}$ Section of Pediatrics, Department of Medical Sciences, University of Ferrara, Ferrara, Italy
}

OPEN ACCESS

Edited by:

Amelia Licari,

University of Pavia, Italy

Reviewed by:

Maria Serena Longhi,

Harvard Medical School,

United States

Fernando Alvarez,

Université de Montréal, Canada

*Correspondence:

Giuseppe Maggiore

giuseppe.maggiore@unife.it

Specialty section:

This article was submitted to

Pediatric Immunology,

a section of the journal

Frontiers in Pediatrics

Received: 11 June 2019 Accepted: 04 September 2019 Published: 20 September 2019

Citation:

Sciveres M, Nastasio S and Maggiore G (2019) Novel Diagnostic and Therapeutic Strategies in Juvenile

Autoimmune Hepatitis.

Front. Pediatr. 7:382.

doi: 10.3389/fped.2019.00382
Juvenile autoimmune hepatitis $(\mathrm{JAlH})$ is a rare, chronic, inflammatory disease of the liver characterized by a complex interaction between genetic, immunological, and environmental factors leading to loss of immunotolerance to hepatic antigens. It affects both children and adolescents, most commonly females, and its clinical manifestations are quite variable. JAlH is progressive in nature and if left untreated may lead to cirrhosis and terminal liver failure. Although $\mathrm{JAlH}$ was first described almost 50 years ago, there have been few significant advances in the clinical management of these patients, both in terms of available diagnostic tools and therapeutic options. Aminotransferase activity, class $\mathrm{G}$ immunoglobulins and autoantibodies are the biomarkers used to diagnose $\mathrm{AlH}$ and monitor treatment response alongside clinical and histological findings. Despite their utility and cost-effectiveness, these biomarkers are neither an accurate expression of AlH pathogenic mechanism nor a precise measure of treatment response. Current standard of care is mainly based on the administration of steroids and azathioprine. This combination of drugs has been proven effective in inducing remission of disease in the majority of patients dramatically improving their survival; however, it not only fails to restore tolerance to hepatic autoantigens, but it also does not halt disease progression in some patients, it is often needed life-long and finally, it has deleterious side-effects. The ideal therapy should be enough selective to contrast immune-mediated live damage while preserving or potentiating the ability to develop permanent tolerance vs. pathogenic autoantigens. By reviewing the state of the art literature, this article highlights novel diagnostic and therapeutic strategies for managing pediatric $\mathrm{AlH}$ with a special focus on new strategies of immunotherapy. These promising tools could improve the diagnostic algorithm, more accurately predict disease prognosis, and provide targeted, individualized treatment.

Keywords: autoimmune liver diseases, autoimmune hepatitis, immunosuppressive therapy, B cell depletion, Tregs, monoclonal antibodies

\section{INTRODUCTION}

Autoimmune hepatitis (AIH) is an inflammatory disease of the liver of unknown etiology characterized by a loss of immune tolerance against liver antigens, resulting in a progressive destruction of the hepatic parenchyma and leading, if untreated, to end-stage liver disease. It affects all ages with a peak of incidence in pediatric age, where it is referred to as Juvenile Autoimmune 
Hepatitis (JAIH) (1). JAIH follows a chronic but fluctuating course and is characterized by female predominance, elevated serum gamma globulins, presence of circulating autoantibodies and interface hepatitis on liver histology (2).

JAIH may present at any age from infancy to adolescence with an incidence reported of 0.4 and a prevalence of 3.0 per 100,000 children, respectively (3).

JAIH is usually symptomatic, presenting primarily as acute hepatitis, with nausea, vomiting, abdominal pain and jaundice $(2,4,5)$. Such presentation can represent a real acute-onset or an acute exacerbation of long-standing liver disease but fulminant or sub-fulminant form of JAIH may also be observed (6). Clinical signs of chronic liver disease or non-specific symptoms, such as fatigue or even fortuitous findings of increased serum transaminases activity in an otherwise apparently healthy child may also be types of presentation. Symptoms and signs of a wide variety of extra-hepatic autoimmune diseases could also lead to the diagnosis of a JAIH; in particular, celiac disease has been diagnosed with higher prevalence than expected in patients with JAIH (7). JAIH can also be part of a multiorgan or systemic autoimmune disease, such as Systemic Lupus Erythematosus (SLE), Autoimmune Polyendocrinopathy Syndrome (APECED), immunodysregulation polyendocrinopathy enteropathy $\mathrm{X}$ linked syndrome (IPEX), lymphoprolipherative syndromes, and STAT 1 gain of function or common variable immune deficiencies (8).

\section{Diagnosis of Autoimmune Hepatitis}

Diagnosis is often challenging and is based on a combination of clinical, biochemical, immunological and histological criteria along with the exclusion of all known causes that may share features mimicking JAIH (9). Specific circulating autoantibodies are essential biomarkers of the disease (10): AIH type 1 is characterized by anti-Smooth Muscle Antibodies (SMA) and/or anti-Nuclear Antibodies (ANA), AIH type 2 is defined by the detection of anti-Liver-Kidney Microsomal antibody type 1 (LKM1) and/or of anti-Liver-Cytosol antibody type 1 (LC1) (11). ANA are directed against multiple nuclear antigens; ASMA recognizes mainly actin filaments (F-actin); anti LKM1 are directed against the Cytochrome P450 2D6 (CYP2D6) in the endoplasmic reticulum of hepatocytes (12); anti LC1 recognizes the Formimino-Transferase Cyclodeaminase (FTCD) in the hepatocytes cytosol (13). LKM1 and LC1 are the most specific autoantibodies and are probably implicated in the pathogenesis of AIH type $2(14,15)$.

About $20 \%$ of children with clinical, biochemical, and histological feature of autoimmune hepatitis lack both typical and non-typical autoantibodies, such as anti-soluble liver antigen (anti-SLA) or atypical perinuclear anti-neutrophil cytoplasmic antibody (pANCA). These patients represent a heterogeneous group of inflammatory liver disorders, defined as "seronegative autoimmune hepatitis" (16). These children promptly respond to immunosuppressive therapy and their liver disease may relapse when immunosuppressive therapy is discontinued.

A diagnostic scoring system for AIH based on clinical, laboratory and histologic criteria was first proposed by the International Autoimmune Hepatitis Group in 1993 and then

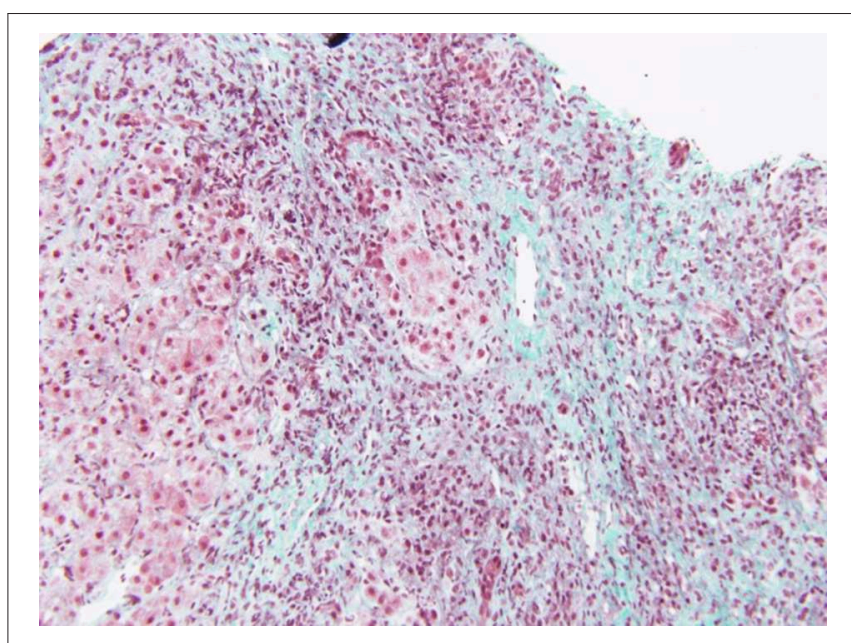

FIGURE 1 | Centrolobular inflammation and fibrosis in a patient with acute presentation of AlH. Trichrome staining showing fibrosis around the central vein and lymphocytic inflammation. Bridging necrosis is also present, between the central vein and a portal tract. Disorganization of the lobular structure is evident.

revised in 1999 (17). This scoring system can also be useful in children, replacing alkaline phosphatase with gamma glutamyltransferase (GGT) activity (18). A simplified diagnostic score with high specificity was more recently proposed, although it has low sensitivity in children $(19,20)$.

Liver biopsy is often needed to establish diagnosis in nontypical cases. Histology allows grading of necro-inflammation, and staging of fibrosis. Most biopsies from children with JAIH show moderate to severe interface hepatitis and lobular inflammation $(2,5,6)$ (Figure 1). Interface hepatitis consists of intense portal and periportal mononuclear cell infiltrate, consisting of $\mathrm{CD} 4$ and $\mathrm{CD} 8 \mathrm{~T}$ cells, macrophages and, occasionally, eosinophils (Figure 1). Emperipolesis, based on entry of CD8 T-lymphocytes into hepatocytes is considered a highly specific feature of autoimmune hepatitis and its presence is associated with more severe necroinflammatory features and more advanced fibrosis (21).

More than half of the biopsies specimens show a variable degree of bridging fibrosis. The presence of cirrhosis at the onset ranges in published series between 40 and more than $80 \%$ of patients $(2,4-6)$. Although fibrosis can regress in patients with complete response to treatment, it is not clear from what stage of liver parenchyma destruction an improvement can be expected.

In presence of biliary lesions a biliary imaging is recommended to exclude main bile ducts injury, thus the possibility of autoimmune sclerosing cholangitis (ASC) (9).

\section{First Line Treatment}

Treatment of JAIH relies on immunosuppressive therapy, administered early and for several years, to avoid relapse. The main goal of the treatment is to obtain complete remission, defined as strict normalization of serum activities of ALT/AST, and of immunoglobulin $G$ values, as well as of the liver function (albumin, clotting factors). Prednisolone or prednisone 
and azathioprine constitute the so-called conventional firstline treatment of JAIH. AIH steroid-responsivity has been known for almost 5 decades now, since the first randomized, controlled treatment trials in adults documented that prednisone administered alone or in combination with azathioprine, dramatically improves symptoms, laboratory tests, histologic findings, and immediate survival (22).

Large series of children treated with conventional therapy have been reported (23-25): prednisone is usually administered orally at $2 \mathrm{mg} / \mathrm{kg} /$ day (up to a maximum of $60 \mathrm{mg} /$ day), azathioprine is administered at the initial dose of $1 \mathrm{mg} / \mathrm{kg} /$ day, which can be further increased up to $2.5 \mathrm{mg} / \mathrm{kg} / \mathrm{day}$ until sustained biochemical remission is achieved. High serum aminotransferases values and impairment of prothrombin time (PT) are considered as an indirect indicator of liver cell necrosis, i.e., severity of disease, and a guide for modulating immunosuppression. Lower doses of prednisone can be administered at the beginning of treatment to children with mild or moderate increase of liver enzymes, normal PT and a low grade of inflammation on the liver biopsy. The best timing of introduction of azathioprine is still under debate. Steroids can be started as the initial treatment with azathioprine added later. Alternatively, combination therapy can be initiated at the onset of treatment with reports of increased efficacy (26). Conventional treatment is associated with a measurable clinical and laboratory improvement within 8 weeks in over $80 \%$ of patients; however, several months may be needed to completely normalize biochemical parameters. Steroids may lead to permanent recovery of liver function, with avoidance or delay of liver transplant also in cirrhotic patients showing signs of liver failure but immunosuppression carries the risk of severe infections that are the most frequent cause of morbidity and mortality in this subgroup of patients (27). In most patients, high doses of prednisone are necessary for a relatively long period, leading to the development of harmful adverse effects. Most frequent are growth impairment and weight gain. The latter is associated with changes in the body image that often compromise the adherence to the therapeutic plan, mainly in pubertal girls and young adults $(23,28)$. Once remission is achieved, the aim is to maintain it in the long term with the lowest possible dose of drugs. Prednisone is progressively stopped and the patient is maintained on azathioprine monotherapy before complete discontinuation of treatment (1). The optimal duration of the immunosuppressive treatment is unknown. Current recommendation is to treat for at least 3 years, attempting withdrawal of treatment only in case of persistent and complete biochemical remission with absent or very low titer autoantibodies (9).

Relapses may occur at any time during treatment and after treatment has been discontinued, even in the absence of triggering factors.

\section{Current Alternative Treatments}

Although conventional treatment with steroids \pm azathioprine allows to achieve remission in most patients, in cases of initial treatment failure or multiple relapses during tapering or discontinuation attempts, alternative therapies are often proposed.
Cyclosporine (CSA) is a powerful immunosuppressant that has been successfully used in patients with JAIH as a shortterm initial treatment alternative to steroid-azathioprine or as a salvage treatment $(29,30)$. The main side effects of CSA include nephrotoxicity, arterial hypertension and gastrointestinal and neurological toxicity. Minor but frequent side effects are Hypertrichosis and gum hypertrophy; although transient they occasionally can influence adherence to treatment. Since 1985, the use of CSA has been documented in 133 adults with autoimmune hepatitis. CSA was used as a salvage therapy and showed an overall positive response of any degree in about $93 \%$ of patients and a negative response, defined as no response, non-compliance, or drug intolerance in $7 \%(31,32)$.

Regarding pediatric patients, there are only five major publications in which CSA is mostly administered for short periods, mainly to induce remission, as a bridge to a conventional treatment $(29,30,33-35)$.

Furthermore, effectiveness of CSA was similar to steroids as a salvage therapy in children with JAIH and liver failure (27). Prolonged CSA treatment for autoimmune pediatric liver disorders was first reported in 2004 with an excellent safety profile (34), confirmed also in a recent follow up study (35).

A recent meta-analysis by Zizzo et al. confirmed that CSA has the highest short-term response rate (86\%) in conventional treatment-refractory children with autoimmune hepatitis (36).

Besides CSA, a wide range of immunosuppressive drugs has been used in small series of children (37).

Mycophenolate Mofetil (MFM) is the second most effective drug for conventional treatment-refractory children with JAIH after cyclosporine (36\% remission rate at 6 months) (36). The main concern in the use of MMF is the lack of knowledge regarding its therapeutic range, and toxic threshold; moreover, MFM is more expensive than azathioprine and is absolutely contraindicated during pregnancy.

Recently, Budesonide, a corticosteroid with potential fewer side effects than other glucocorticoids, emerged as an alternative first-line treatment in association with azathioprine. When comparing the effects of budesonide vs. prednisone, both in combination with azathioprine, budesonide did cause fewer side effects than prednisone; however, after 12 months, only $46 \%$ of the patients treated with budesonide achieved complete remission (38). The low proportion of remission observed in this study does not support its use as first-line treatment of AIH $(1,39)$.

mTOR inhibitors as sirolimus or everolimus have been used as salvage therapy with good results in few published adult patients $(40,41)$.

Liver transplantation represents a therapeutic option for a small proportion of patients under two main circumstances: patients presenting with acute liver failure that does not respond to salvage therapy with rescue immunosuppression, and patients with cirrhosis with end stage liver disease.

\section{UNMET CLINICAL NEEDS}

\section{Diagnostic Issues}

To this day, the diagnosis of AIH in children remains challenging and burdened by several unmet clinical needs. First of all, 
a highly specific single diagnostic test for the diagnosis of $\mathrm{AIH}$ is lacking. Furthermore, diagnosis may be complicated or potentially delayed by the fact that $\mathrm{AIH}$ is characterized by a very heterogeneous clinical presentation and its diagnosis requires the exclusion of all other causes of liver disease $(1,9)$. Class $G$ immunoglobulins and autoantibodies are the biomarkers used to aid in the diagnosis of AIH alongside the more invasive liver biopsy. However, these biomarkers are neither an accurate expression of AIH pathogenic mechanism, nor do they univocally correlate with the degree of inflammation and fibrosis present on liver biopsy. Histology presents its own challenges, interface hepatitis is the histological hallmark of AIH but it is not exclusive to this condition and the typical histology comprising interface hepatitis, portal lymphoplasmacytic infiltrate, rosette formation, and emperipolesis, is observed in only $56 \%$ of children with autoimmune liver disease $(9,42)$. Unfortunately, both the scoring system created by the International Autoimmune Hepatitis Group and the simplified version proposed in 2008 have limited utility in pediatric patients (18). Moreover, AIH lacks markers and clinical tools able to provide the adequate patient risk stratification at diagnosis, which is necessary to enable providers to identify a tailored treatment. Lastly, there are no available biomarkers that might effectively guide the treatment.

In summary, main open questions are: how fast to decrease initial attack therapy (usually steroids); how long to treat before attempting to stop; when to attempt to stop treatment; risk stratification for relapse after stopping treatment. Immunoglobulins $\mathrm{G}$ level, presence or titer of autoantibodies and even liver histology are not predictive of success, but clinicians need to consider these elements in the absence of stronger predictors.

\section{Treatment Issues}

Overall efficacy of available therapies along with the relative rarity of this disease has, for decades, hindered the implementation of clinical trials involving a reasonable number of patients. Although the conventional treatment with prednisone and azathioprine is associated with a high remission rate $(1,2,23)$, 3 to $16 \%$ of children will undergo liver transplantation despite steroids treatment and 69 to $94 \%$ of pediatric patients will relapse after drug withdrawal $(1,2,6)$. Most JAIH patients remain on treatment until adult age.

As for adult patients initial treatment failure occurs in 7-10\% of patients and another $15 \%$ achieve only partial response (43). Relapse occurs after treatment withdrawal in 50-87 and 60-81\% of patients become treatment-dependent (44). AIH progresses to cirrhosis in as many as $40 \%$ and $1-6 \%$ of patients with cirrhosis develop hepatocellular carcinoma (45).

The combination of these data with the evidence of steroid related side effects has constituted, and currently remains a compelling reason to refine management strategies and pursue new therapeutic options.

The main pitfall of available drugs is their complete nonselectivity. Most available immunosuppressant agents interfere indiscriminately both with the effector side of the immune system and with the regulatory compartment, thus preventing achievement of a durable desensitization against the pathogenic autoantigens, which remain unknown in most cases. However, modern techniques of molecular biology allowed for the development of powerful molecules that target single aspects of immune activation. Some of them might represent a Copernican revolution, in the field of $\mathrm{AIH}$ treatment, when compared with old generation immunosuppressant drugs.

\section{NEW STRATEGIES FOR DIAGNOSIS}

With the advancements in molecular biology and sequencing techniques, the potential role of new biomarkers for screening and diagnosis of autoimmune hepatitis has been explored. Recent data has shown the expression of liver specific microRNAs (miRNAs) in different types of liver disorders suggesting their clinical utility as diagnostic tools for a variety of liver conditions (46). MicroRNAs (miRNAs) represent a class of endogenous, short non-coding RNAs that regulate the expression of target genes by binding to complementary regions of transcripts to repress their translation or cause mRNA degradation (47). After the presence of extracellular miRNA was discovered in body fluids, a specific miRNAs signature in different liver diseases was also described (48).

In 2015, Migita et al. investigated the circulating miRNA profiles of 46 patients with $\mathrm{AIH}$ and compared them to those of 40 patients with chronic hepatitis $\mathrm{C}$, and 13 healthy controls. Patients were screened for 2555 miRNA using microarray and quantitative real-time PCR analysis (49). Circulating miR-21 and miR-122 were found to be significantly elevated in patients with AIH, leading to a unique miRNA expression profile. Moreover, miR-21 and miR-122 serum levels correlated with alanine aminotransferase levels and were inversely associated with increased stages of hepatic fibrosis. In contrast levels of circulating miR-21 showed a significant correlation with the histological grade of inflammation in AIH. A positive correlation between miR-21 expressed in liver tissue and ALT values was also showed in 19 patients with autoimmune liver diseases including autoimmune hepatitis, primary biliary cirrhosis, primary sclerosing cholangitis, and overlap syndrome (50).

More recently a study examined the serum miRNA profiles of 28 patients with a variety of liver disorders, including autoimmune hepatitis, as well as 4 control subjects, aiming to see whether circulating miRNAs could be used to differentiate between types of liver injury. The authors identified 37 miRNAs whose levels were different between all types of liver diseases. Interestingly, individual miRNA could not distinguish the specific type of liver disease and the authors suggest this might be due to the similarity in liver pathology beyond type of liver injury. However, the profiles of 37 miRNAs could clearly differentiate patients with liver injury from control subjects, and furthermore, could distinguish different types of liver disease (48). Nonetheless the study group is very small and includes only 4 controls and no definitive conclusions can be drawn.

The programmed death-1 receptor (PD-1, CD279) with its ligands PD-L1 (B7-H1) and PD-L2 (B7-DC) constitutes an inhibitory pathway that suppresses $\mathrm{T}$ cell activation and decreases lymphocyte proliferation (46). PD-1 is also found to be increased in exhausted T cells (51). PD-1, PD-L1, and PD-L2 have been detected in the liver tissue of patients with $\mathrm{AIH}$ and it has been 
hypothesized that impaired regulation of the PD-1 axis may play a role in the development of autoimmune liver diseases (52).

In 2014, a study investigated the presence of anti-PD-1 antibodies, measured by indirect enzyme-linked immunosorbent assay, in sera of 52 type $1 \mathrm{AIH}$ patients, 24 patients with druginduced liver injury (DILI), 30 patients with acute viral hepatitis $(\mathrm{AVH}), 11$ patients with primary sclerosing cholangitis (PSC), and 62 healthy volunteers (53). The authors found that the prevalence of serum anti-PD-1 antibodies was greater in type 1 AIH (63\%) compared to DILI (8\%), AVH (13\%), PSC (18\%) as well as healthy controls (3\%) suggesting its potential usefulness for the discrimination of type $1 \mathrm{AIH}$ from other causes of liver injury. Furthermore, titers of serum anti-PD-1 antibodies were found to correlate with serum levels of bilirubin and alanine aminotransferase (ALT) but not with serum immunoglobulin G levels in type $1 \mathrm{AIH}$ patients. These results were confirmed by a multicenter validation study on 71 patients with $\mathrm{AIH}$ and 37 patients with DILI (54). This study confirmed that serum levels of anti-PD-1 antibodies were higher in type $1 \mathrm{AIH}$ patients than in DILI ones and the receiver operating curve analysis showed that measurement of anti-PD-1 antibodies was useful for the discrimination of type 1 AIH from DILI.

Although preliminary results on miRNA and PD-1 are promising, future studies are warranted to validate these findings in larger prospective studies and to demonstrate their added value and/or superiority to conventional laboratory test and histological examination.

\section{PERSPECTIVES FOR NEW A NEW GENERATION OF BIOMARKERS}

\section{Programmed Death-1 Axis}

The components of PD-1 axis are potentially not only a valid auxiliary diagnostic marker for type $1 \mathrm{AIH}$, but also a marker of disease activity and risk of relapse. Aarslev et al. investigated the expression of soluble PD-1 (sPD-1), in 47 healthy controls and 67 AIH patients, 9 with active disease, 31 responders and 27 incomplete-responders to standard treatment (55). sPD-1 is shed from activated $\mathrm{T}$ cells and its levels may therefore reflect in vivo T-cell activation. In this cross-sectional study, sPD-1 was found to be significantly elevated in AIH patients with active disease and in incomplete responders to standard treatment compared to responders and healthy controls.

\section{Macrophage Migration Inhibitory Factor (MIF) CD74-Ligand}

Macrophage migration inhibitory factor (MIF) is a proinflammatory cytokine that mediates the host response to infection and stress by activating innate and adaptive immune pathways and in particular promotes Th1 immunity, which is a key element of AIH pathophysiology (56). Recently, MIF has been associated with a variety of immune-mediated diseases such as rheumatoid arthritis (RA), systemic sclerosis, and inflammatory bowel disease. CD74, the main ligand of MIF, is a transmembrane protein expressed on several cell types including antigen-presenting cells, epithelial cells and stromal cells. MIF and CD74, measured by ELISA in the serum of 165 patients with $\mathrm{AIH}, \mathrm{PBC}$, and controls, were found to be significantly higher in patients with AIH than in healthy controls (57). The calculated serum ratio of CD74/MIF was inversely correlated with serum ALT in AIH patients receiving conventional treatment who experienced a relapse, suggesting that the concentration of MIF in relation to its ligand may constitute a potential marker of immunogenic inflammation in the liver in AIH. Two previously identified polymorphisms with clinical significance in the MIF promoter have also been analyzed in DNA samples from more than 500 patients with AIH, PBC, and controls (57). A higher frequency of the pro-inflammatory and high expression-794 CATT7 allele was found in AIH patients compared to PBC ones. Serum concentrations of MIF and its circulating ligand CD74 were also found to be higher in Japanese AIH patients when compared to healthy subjects (58). In this study MIF genotypes were also investigated and then correlated with serum ALT levels and steroid requirements.

In AIH patients with MIF-173 CC/GC genotypes serum ALT levels and steroid requirement were found to be higher than in patients with MIF-173GG. This suggested that the MIF genotype containing the MIF -173C polymorphism could be a marker of disease severity in AIH.

\section{Soluble CD163}

The role of CD163 as a biomarker of $\mathrm{AIH}$ was recently investigated. CD163 is the receptor for haptoglobin-hemoglobin complexes and is expressed almost exclusively on macrophages and monocytes $(59,60)$. Once activated, the receptor sheds and appears in the blood as soluble (s)CD163 therefore constituting a surrogate of macrophage activity. It is elevated in multiple inflammatory disorders including chronic viral hepatitis, acute liver failure and cirrhosis (61).

In 2016 the role of sCD163 in autoimmune liver disorders was first investigated in 121 patients: 101 had AIH type-1; 13 had variant syndromes of AIH type-1; primary biliary cholangitis; 7 of AIH type-1 and primary sclerosing cholangitis (60). sCD163 was significantly elevated in active AIH, normalizing in complete responders receiving prednisone and azathioprine, but remaining high in the incompletely responding cases. sCD163 was positively associated with ALT, IgG and bilirubin values, and negatively with coagulation factors. Furthermore, sCD163 rapidly fell upon treatment in treatment naive patients. If such results are confirmed in future prospective studies, sCD163 could thereby serve as a biomarker of insufficient treatment and prognosis.

\section{B Cell Activating Factor}

B-cell activating factor (BAFF) is a member of the tumor necrosis factor superfamily and it has an important role in the development of B cells. It recently emerged as a regulator of $\mathrm{T}$ cell function and appeared to play a central role in the development of autoimmunity (62). When serum BAFF levels were examined in 55 patients with $\mathrm{AIH}, 14$ patients with acute hepatitis, 33 patients with chronic hepatitis $\mathrm{C}$, and 33 healthy controls, they were higher in AIH patients (63). Moreover, there was a positive correlation between BAFF and ALT, total bilirubin, and soluble 
CD30 in patients with AIH. However, no correlation was found between BAFF and levels of gammaglobulins or ANA titers. Steroid treatment resulted in marked reduction in serum BAFF levels in AIH patients. When patient were treated with steroids, a dramatic decrease in BAFF was seen by 2 weeks of treatment in parallel to ALT serum levels suggesting a correlation with disease activity.

Despite the potentially interesting role of these biomarkers it should again be pointed out how some of these biomarkers have been found to be increased both in multiple autoimmune disorders and other non-autoimmune inflammatory liver conditions, clearly indicating the need for further, and more conclusive studies.

\section{NEW TOOLS FOR BIOLOGICAL THERAPY}

During the last two decades, the progressive introduction of engineered, chimeric or humanized, monoclonal antibodies represented a milestone in a new era of the treatment of immune mediated diseases.

They are usually manufactured to aim at one specific branch of the cytokine network and interfere with the signal mediated by the target molecule at various levels.

In some instances, this approach led to modify the natural history of the disease, as for example, TNF $\alpha$ blockers in inflammatory bowel diseases or IL-1 antagonists in RA.

An essential condition to obtain such results is a comprehensive knowledge of the pathogenesis and identification of the up-regulated signaling pathways. Unfortunately, this is not the case for AIH; therefore, the introduction of monoclonal autoantibodies in the treatment of AIH was somewhat empirical, based on analogies with other autoimmune disease, and usually in single cases or small series of patients (Table $\mathbf{1}$ ).

\section{Targeting the TNF $\alpha$ Pathway}

A few arguments link the $\mathrm{TNF} \alpha$ signaling pathway to pathogenesis of autoimmune hepatitis, mostly the high levels found in liver and blood of patients compared to controls. Early observations pointed the Adenine/Guanine polymorphism at position 308 of the TNF $\alpha$ gene (64). In Caucasian adults, it was associated with high basal and inducible level of $\mathrm{TNF} \alpha$, with early onset of disease and with poor response to treatment (65). More recently high levels of circulating $\mathrm{TNF} \alpha$ were found in pediatric onset disease (66) and a meta-analysis confirmed the role of the TNF- $\alpha-308 \mathrm{~A} / \mathrm{G}$ as a risk factor (67).

Infliximab (IFX) is a recombinant humanized chimeric antibody widely used for the treatment of RA, psoriasis, ankylosing spondylitis, ulcerative colitis, and Crohn colitis. The mechanism of action is neutralizing soluble and transmembrane forms of TNF $\alpha$ thus hampering the activation of effector T-cells.

To date, two small series and two case reports describe the outcome of IFX treatment in 24 patients (68-71).

Weiler-Normann et al. described 11 adults with refractory AIH treated with 3 doses of $5 \mathrm{mg} / \mathrm{kg}$ IFX as attack therapy and one infusion every 4 to 8 weeks as maintenance therapy according to the clinical course (68). Results were encouraging, $72 \%(8 / 11)$ of patients achieved full biochemical remission, six of them with
TABLE 1 | Potential approaches for immunoterapy of AlH patients.

\begin{tabular}{|c|c|c|}
\hline Mechanism & Molecule & Experience \\
\hline Anti-TNF $\alpha$ antibodies & $\begin{array}{l}\text { Infliximab } \\
\text { Adalimubab } \\
\text { Etanercept }\end{array}$ & $\begin{array}{l}A \\
B \\
B\end{array}$ \\
\hline Anti-CD20/BAFF antibodies & $\begin{array}{l}\text { Rituximab } \\
\text { Belimubab } \\
\text { lanalumab }\end{array}$ & $\begin{array}{l}\mathrm{A} \\
\mathrm{B} \\
\mathrm{B}^{*}\end{array}$ \\
\hline Anti-IL-17 antibodies & $\begin{array}{l}\text { Secukinubab } \\
\text { Ixekizumab } \\
\text { Brodalumab }\end{array}$ & $\begin{array}{l}B \\
B \\
B\end{array}$ \\
\hline Anti-IL-12/IL-23 antibodies & $\begin{array}{l}\text { Ustekinumab } \\
\text { Briakinumab }\end{array}$ & $\begin{array}{l}B \\
B\end{array}$ \\
\hline Anti-IL-6 antibodies & Tocilizumab & B \\
\hline Inhibitors of JAK & $\begin{array}{l}\text { Tofacitinib } \\
\text { Baricitinib }\end{array}$ & $\begin{array}{l}B \\
B\end{array}$ \\
\hline ROR $\gamma$ t inhibitors & - & C \\
\hline Polyclonal Tregs & - & $\mathrm{B}^{*}$ \\
\hline CAR TRegs & - & $\mathrm{B}^{\star *}$ \\
\hline Low dose IL-2 administration & $\mathrm{IL}-2$ & $A^{*}$ \\
\hline IL-2 modifiers & F5111.2 & C \\
\hline Mesenchymal stem cells & - & $\mathrm{B}^{*}$ \\
\hline
\end{tabular}

A: clinical experience in AlH; B: clinical experience in other autoimmune diseases; C: no clinical experience, only in vitro or animal model data. ${ }^{*}$ clinical trial currently ongoing. ${ }^{* *} n o t$ directly applicable to AlH patients.

complete normalization of IgG levels, and most of them could continue therapy for more than 1 year. In the first pediatric report infliximab allowed to achieve a sustained biochemical response while weaning steroids, improving quality of life and allowing deferral of liver transplantation in a 10 years old girl non responsive to high dose steroids, azathioprine, mycophenolate and tacrolimus (70).

A recent study reviewed retrospectively the records of 11 pediatric patients with inflammatory bowel disease (IBD) and autoimmune liver disease (2 AIH and 9 with ASC). All patients received IFX $(5 \mathrm{mg} / \mathrm{kg})$ for their IBD and 6 switched to adalimumab due to allergic reaction or non-response. Liver disease improved in 5 patients while in the remaining cases did not show any negative effect (71).

Tolerability of IFX was not homogeneous in this series. More than $50 \%$ of adult patients developed infectious complications, a few of which were serious (68). Conversely IFX was very well tolerated in children or young adolescents, only 1 out of 12 patients suffered a CMV reactivation easily treated (71).

Besides the infectious risk, the major concern about IFX therapy is the potential risk to trigger other autoimmune diseases (72). This effect descends directly from the complex physiological role of TNF $\alpha$. The differential activation of the two TNF receptors (TNFR1 and TNFR2) expressed on $\mathrm{T}$ cells lead to opposite effects. Stimulation of TNFR1 activate effector T-cells and drives inflammatory response but activation of TNFR2, expressed on regulatory $\mathrm{T}$ cells, expands the pool of these cells preventing autoimmunity, (Figure 2) and attenuates inflammation (73). Moreover, TNF $\alpha$ blockade interferes with the normal cytotoxic $\mathrm{T}$ lymphocyte suppression of self-reactive B-cell population and 
with the TNF $\alpha$-mediated apoptosis of activated $\mathrm{T}$ lymphocytes facilitating the expansion of auto-reactive clones (74).

Liver diseases with detection of conventional $\mathrm{AIH}$ autoantibodies (ANA, ASMA, and anti-LKM antibody), along with histologic characteristics consistent with autoimmune hepatitis (i.e., interface hepatitis, lymphoplasmacytic infiltrate, and bridging fibrosis) have been reported in dozens of adult patients receiving anti-TNF $\alpha$ therapy to treat various autoimmune diseases. However, it is not clear whether autoimmune features in liver injury during the treatment are primitive or secondary because of the potential role of IFX in causing direct liver damage (75). In every case these features are only anecdotally reported in children and the risk seems marginal (76).

Moreover, stimulation of TNFR2 receptors could be used therapeutically. Vaccination with bacillus of Calmette-Guérin is currently being tested for treatment of various autoimmune diseases and this effect seems to be mediated by the expansion of regulatory T-cells and by selective death of auto reactive lymphocytes caused by activation of TNF $\alpha$ cascade (77).

\section{Blocking B-Cells Activity}

Although pathogenesis of AIH is poorly comprised, a number of observations suggest that the role of T-cells is prominent (78). Analysis of portal lymphoplasmacytic infiltrate in liver biopsies of patient with AIH shows that the large majority of lymphocytes are CD4 T-cells with Th1 functional differentiation (79). The final effectors of liver damage are most likely CD8 T-cells, located at the interface between portal tracts and hepatocytes (80), which are able to cause liver injury directly but also through a bystander effect mediated by soluble cytokines (TNF $\alpha$, IFN $\gamma$ ) produced by activated T-cells (81). Although hypergammaglobulinemia and the presence of autoantibodies is a hallmark of AIH, it is unlikely that they have a significant pathogenic role. Even if immunoglobulins found on the surface of hepatocytes obtained from AIH liver biopsies could mediate antibody-mediated cell cytotoxicity (82) the passive transfer of serum alone is not able to cause disease in a murine model, as both genetic predisposition and environmental triggers are needed (83). Nevertheless, Bcells likely play a pivotal role in the immunological cascade leading to recognition of auto antigens, mainly acting as APC and thus stimulating activation and proliferation of antigenexperienced T-cells. In AIH type 2 there is a large overlap between the CYP2D6 peptide sequences that are recognized by LKM1 autoantibodies and CYP2D6-specific CD4 cells, which clearly demonstrates the large interplay between $\mathrm{B}$ and $\mathrm{T}$ cells $(84,85)$.

Even though the B-depletion strategy in animal models produced contrasting results $(86,87)$, thanks to the availability of rituximab (RTX), which is well known and widely used in other diseases, this approach has been tested in clinical practice as a rescue therapy.

Rituximab is a chimeric monoclonal antibody that targets the CD20 surface antigen on B-cells causing B-cell depletion (88). It is currently used for treatment of B-cell malignancies such as non-Hodgkin lymphoma and post transplantation lymphoproliferative disease, as well as autoimmune disorders such as RA and ANCA-positive vasculitis. A total of 13 patients

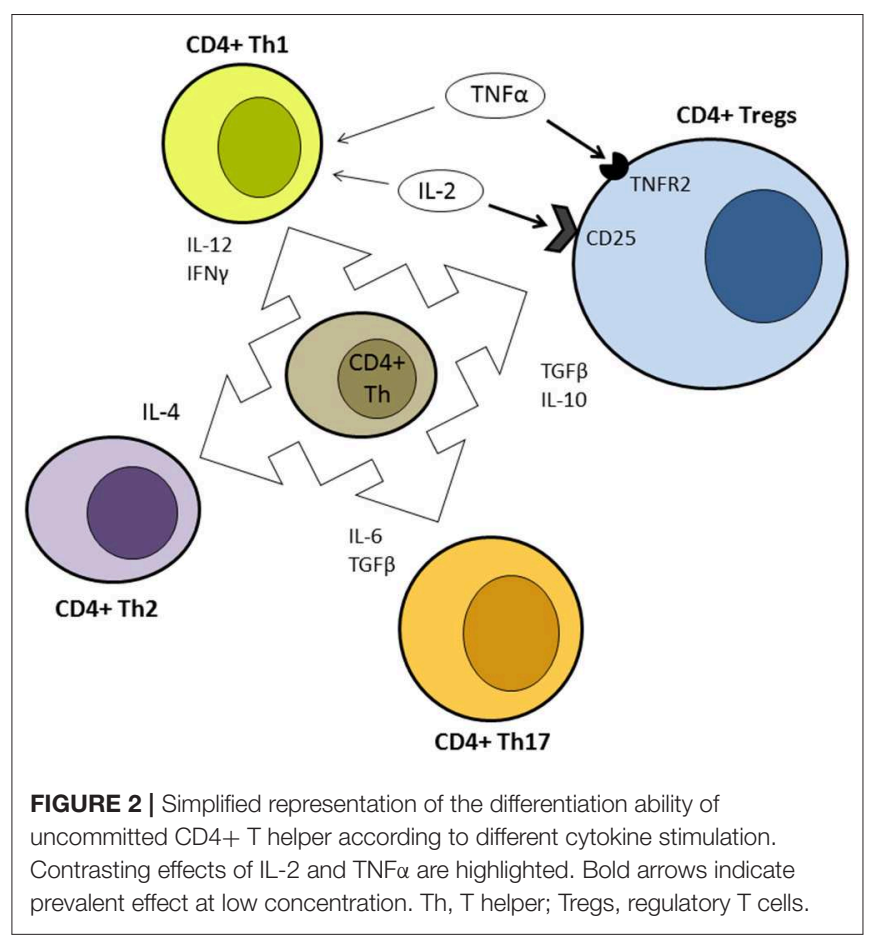

who received rituximab as second line therapy for AIH are currently described in literature (89-96). Aside from 4 case reports, only a single study with a small series of adult patient was published. In 2013 Burak et al. reported on 6 patients with incomplete response to conventional therapy receiving 2 doses of 1,000 mg of RTX (89). Transaminases improved in all patients and IgG levels trended downward. Biochemical results were confirmed histologically because at week 48 all patients underwent a control liver biopsy, which showed significantly reduced portal inflammation. A durable weaning of steroid dose was possible in 4 patients, but the only subject who was taken off prednisone at week 24 experienced a relapse at week 46 , which temporarily required a higher dose of prednisone to control his disease. Overall, RTX was effective, at least as a steroid sparing agent, but more importantly, it was safe. No adverse reactions were recorded, and at week $72 \operatorname{IgG}$ levels were on the lower side of normal range in all patients; moreover, two infusions did not cause severe hypogammaglobulinemia in adult patients (89).

In regards to pediatric patients, in 2013 D'Agostino et al. reported on 2 children with severe, refractory, type 1 autoimmune hepatitis in which rituximab was administered as rescue treatment allowing to achieve complete clinical and biochemical remission without side effects and without permanent hypogammaglobulinemia (95). A more aggressive protocol was used and patients received a complete cycle of 4 infusions at dose of $375 \mathrm{mg} / \mathrm{m}^{2}$ plus a variable number of doses every 4 to 6 months to maintain remission. Prednisone was tapered to a very small dose but suspension was not attempted.

It must be noted that the reported effect of RTX on transaminases parallels the decrease of IgG levels, and it is very slow. Complete remission was achieved from 6 to 12 months later in published series $(89,95)$ but in some cases it was durable. A 
good example is the history of a 16 years girl with very active type 1 disease despite triple immunosuppression (prednisone, CSA, and MMF) who received 4 infusions of RTX as described by D'Agostino. After 6 months, no significant effect was noted as regards of transaminase activity, a few weeks later the girl was lost to follow up. We saw the patient again 2 years later with normal transaminases and IgG levels without taking any drug since she had arbitrarily withdrawn all treatments 2 years before (personal unpublished data).

Despite such little amount of published cases, RTX is extensively used as rescue therapy in clinical practice as showed by a recent real life survey among expert centers (97) and a multicentric study not yet published "in extenso" (98). The most dreaded infectious complication of RTX treatment, however, is a progressive, multifocal, and eventually lethal encephalitis caused by the Polyoma John Cunningham virus (JC), which may occur months or years after the beginning of the treatment (99).

A similar but most selective approach, comparing to antiCD20 antibodies, consists on selective down regulation of the B cell activation factor (BAFF) pathway that is clearly up regulated in AIH patients (63). Biological effects of BAFF comprehend prolonging survival of mature B cells, stimulating IgG production in activated plasmocytes but also stimulating CD4 activated T-cells and probably concurring to differentiation into Th1/Th17 phenotype $(62,100)$. Blockade of the BAFF signal also increases the number of regulatory B cells (100). A humanized antibody against the soluble BAFF called belimumab was approved for treatment of LES. Another antibody, Ianalumab, is currently evaluated in a controlled randomized trial for second line therapy in AIH (Table 2). Lanalumab target selectively the BR3 receptor of BAFF and act with two distinct mode of action, interfering with the BR3 mediated BAFF signal and causing also antibodymediated cytotoxicity. Thus, lanalumab administration should deplete preferentially differentiated $\mathrm{B}$ cells and plasma blasts sparing pro- and pre- $\mathrm{B}$ cells that are instead targeted by anti CD20 antibodies. If the ongoing trial will demonstrate efficacy we could expect a better safety profile than rituximab.

\section{IL-17 and IL-6 Axis: A New Generation of Monoclonal Antibodies}

Th17 lymphocytes, a subset of CD4+ cells, are the more recent characterized phenotype after Th1 and Th2 cells (101). They are generated by activated CD4 cells under differentiation signal given by IL6 and TGF $\beta$ and may constitute one of the first specialized lineage of $\mathrm{T}$ lymphocytes to appear in response of inflammation. Th17 cells secrete mainly IL-17A, IL-17F, IL21, IL-22 but also IL-6 that, along with IL-23, is crucial for survival and expansion of Th17 cells (102) (Figure 2). As the majority of components of adaptive immune system, Th17 cells have proinflammatory and cytotoxic effect but also a regulatory potential to avoid excessive inflammatory response. TGF $\beta$ and IL-2 are negative signals for differentiation and amplification of Th17 cells (103) and IL-22 have anti-inflammatory effect and promote damage repair and tissue regeneration (104).

The positive signal is mediated mainly by IL-17 and IL21 that induce a broad reaction of different cell types to
TABLE 2 | Selection of ongoing interventional clinical trial from a total of 25 trials registered on Clinicaltrial.gov.

\begin{tabular}{|c|c|c|}
\hline Title & Identifier & Status \\
\hline $\begin{array}{l}\text { Use of erythropoietin to expand regulatory } T \\
\text { cells in autoimmune liver disease }\end{array}$ & NCT03842254 & $\begin{array}{l}\text { Enrolling by } \\
\text { invitation }\end{array}$ \\
\hline $\begin{array}{l}\text { ADCC mediated B-Cell depletion and } \\
\text { BAFF-R blockade }\end{array}$ & NCT03217422 & Recruiting \\
\hline $\begin{array}{l}\text { A single-arm, phase Ila, safety and efficacy } \\
\text { trial of selected MSCs in the treatment of } \\
\text { patients with PSC \& AiH }\end{array}$ & NCT02997878 & Recruiting \\
\hline $\begin{array}{l}\text { Safety and efficacy study of regulatory } T \\
\text { cells in treating autoimmune hepatitis }\end{array}$ & NCT02704338 & Unkown status \\
\hline $\begin{array}{l}\text { Liver test study of using JKB-122 in AlH } \\
\text { patients }\end{array}$ & NCT02556372 & $\begin{array}{l}\text { Active. Not } \\
\text { recruiting }\end{array}$ \\
\hline $\begin{array}{l}\text { sPIF clinical study protocol for autoimmune } \\
\text { hepatitis }\end{array}$ & NCT02239562 & $\begin{array}{l}\text { Completed. No } \\
\text { results }\end{array}$ \\
\hline $\begin{array}{l}\text { The role of sodium chloride and the } \\
\text { Treg/Th17 axis in autoimmune hepatitis }\end{array}$ & NCT02050646 & Recruiting \\
\hline $\begin{array}{l}\text { Induction of regulatory T cells by low dose } \\
\text { IL2 in autoimmune and inflammatory } \\
\text { diseases }\end{array}$ & NCT01988506 & Recruiting \\
\hline $\begin{array}{l}\text { Umbilical cord mesenchymal stem cells for } \\
\text { patients with autoimmune hepatitis }\end{array}$ & NCT01661842 & $\begin{array}{l}\text { Unknown } \\
\text { status }\end{array}$ \\
\hline $\begin{array}{l}\text { Effect of high-protein high-fiber diet in } \\
\text { patients with autoimmune hepatitis }\end{array}$ & NCT01655121 & $\begin{array}{l}\text { Completed. No } \\
\text { results }\end{array}$ \\
\hline
\end{tabular}

Selection was done on the basis of the innovative approach to treatment. accessed May 20, 2019.

secrete cytokines (IL-1, IL-6, TNF $\alpha$, IL-8, GM-CSF, G-CSF), chemokines (CXCL1, CXCL10), and metalloproteinases and induce recruitment, activation and migration of Th1 cells and neutrophils (105). IL-2 and IL-17, result of synergistic action of Th1 and Th17 cells, induce hepatocytes to produce IL- 6 and to express class II MHC molecules that boost Th17 cells differentiation and CD8 cells activation $(106,107)$. IL-21 together with TGF- $\beta$ further amplifies Th17 differentiation in an autocrine self-amplification loop.

Patients with AIH show signs of up regulation of IL-17 pathway: they have increased IL-17 blood and liver concentration and more Th17 infiltrating cells than healthy and other chronic liver disease controls $(106,108)$.

Intrahepatic production of IL-17 and other related mediators as IL-6 and IL-23 were associated with disease activity and liver fibrosis (108).

In summary, Th17 cells are pivotal players of early phase of inflammatory response, probably also in AIH. IL-1, IL-6, IL-17, and IL-21 axis are essential to trigger and maintain Th17 response and consequently they are potential therapeutic targets for a new generation of monoclonal antibodies (108) (Figure 2). In animal models Il-17 inhibition was able to improve AIH disease activity, moreover anti-IL-17 antibodies increased regulatory T-cells (Tregs) production and expansion from sera of $\mathrm{AIH}$ patients (109).

Several antibodies that interfere with soluble IL-17, such as secukinubab and ixekizumab, or with IL-17 receptor, such as brodalumab are being tested for various autoimmune diseases 
(Table 1). Published Phase II, randomized, double blind, placebocontrolled studies using these three humanized monoclonal antibodies showed positive results in treatment of Psoriasis. Secukinubab was superior to anti-TNF $\alpha$ in therapy of Psoriasis showing better control of disease and longer lasting effects with a good safety profile as shown by results from the phase 3 FUTURE 2 study and confirmed by data from real word US registry $(110,111)$. Positive results were also described in the clinical trial of secukinumab and ixekizumab in various IL-17- related immune mediated disease, such as Rheumatoid Arthritis (RA), ankylosing spondylitis, and non-infectious uveitis (112-114).

Even promising these results cannot be transposed in therapy of autoimmune hepatitis and pilot clinical studies are needed to confirm preliminary data although the unfavorable outcome of secukinumab for the treatment of Crohn's disease induced caution in clinicians and pharmaceutical companies (115).

Another potential approach to inhibit the IL-17 axis is to target cytokines that are essential for differentiation and survival of Th17 cells as IL-1 $\beta$, IL-6 and IL-23, as mentioned above (108).

IL-12 and IL-23 share the same p40 subunit that is targeted by specific humanized antibodies such as ustekinumab and briakinumab. Both were demonstrated effective and safe in Phase II/III clinical trials for the treatment of active psoriatic arthritis, plaque psoriasis or refractory Crohn's disease $(116,117)$ but only ustekinumab was approved by regulatory authorities and is currently available for use in treatment. Ustekinumab showed very good long-term safety in moderate-to-severe psoriasis after up to 5 years of follow-up, and superiority to etanercept in a large Phase III trial (118). Preliminary favorable data exist with regards to Behçet's disease (119) but it was not effective in trials involving patients with multiple sclerosis and primary biliary cholangitis $(120,121)$. Moreover, antibodies against the IL-23 unique subunit p19 are currently tested in clinical trials with the hope to obtain a more selective action and a better safety profile (122).

Also IL-6, which is essential to induce selection of CD4+ naive lymphocytes toward Th17 differentiation, became a target for immunotherapy. Tocilizumab, a humanized antibody against IL-6 receptor has been approved for therapy of RA, juvenile idiopathic arthritis and giant cell arteritis (123-125) and the field of application is expanding toward other vasculitis and even severe immunoallergic diseases.

The most recent approach for immunotherapy, rather than interfering with a single cytokine, is blocking the intracellular common downstream pathways that react to the interaction between cytokines and their receptors. Potential targets in such perspective are cytoplasmic signaling protein and nuclear transcription factors and drugs are not antibodies but small molecules that are able to cross cellular membranes.

Type I and type II cytokine receptors are a super-family of receptors that recognize over 50 cytokines, interleukins and interferons, including IL-2, IL-4, IL-6, IL-21, all involved at various titer in $\mathrm{AIH}$ pathogenesis. Al members of this family of receptors use Janus kinases (JAK) 1-3 and tyrosine kinases 2 to transfer the input to downstream signal transducers. Consequently, inhibitors of JAK signaling (jakitinibs), have the potentiality to hamper the differentiation in Th17 cells, mainly blocking the IL-6 stimulation (126). Tofacitinib and baricitinib, are small molecules that interfere with the ATP binding domains of kinases, and have been approved for RA and ulcerative colitis treatment. More importantly, tofacitinib proved successful in treating patients with RA where antibodies against single cytokines or single cytokine receptors, such as TNF $\alpha$ and IL-6 (126), were ineffective.

As regards transcription factors, the two key molecules involved in Th17 differentiation are the signal transducer and activator of transcription (STAT) 3 proteins and orphan nuclear receptor $\operatorname{ROR} \gamma$. The specific isoform $\operatorname{ROR} \gamma \mathrm{t}$ was the first transcription factor found to be selectively expressed in TH17 cells and is regulated by STAT3. More recently also ROR $\alpha$ was identified as synergistic of the ROR $\gamma$ t isoform (127). Being the master regulator for Th17 differentiation ROR $\gamma$ t has the potential to be a promising therapeutic target for autoimmune disease (128).

Development of ROR $\gamma \mathrm{t}$ specific inhibitors is one of the most promising fields of research for autoimmune diseases. Moreover, this class of drugs might have a more selective action and consequently better safety profile when compared to kinases inhibitors, which are potent immunosuppressive drugs with relevant infectious complications.

\section{REGOLATORY T-CELLS: CUTTING THE ROOTS OF DISEASE}

Negative selection of self-reactive $\mathrm{T}$ cells in the thymus is the first line of defense against autoimmunity and is responsible for neutralization of most high-affinity $\mathrm{T}$ cell recognizing self-antigens. Nevertheless, accurate selection and/or modulation of $\mathrm{T}$ cell activation in peripheral tissues is pivotal to avoid inappropriate reaction against targets as food antigens, commensal microorganisms, environmental antigens, or simply to avoid excessive damage caused by inflammatory response. A heterogeneous subset of $\mathrm{T}$ cells has the ability to suppress the function of other lymphocytes and it consists of various populations: $\mathrm{CD}^{+}{ }^{+} \mathrm{CD} 25^{+}$Foxp $3^{+}$cells, IL-10-producing $\mathrm{CD} 4{ }^{+}$ Tr1 cells, TGF $\beta$-producing Th3 cells, $\mathrm{CD}^{+}$cells, NK T cells, CD4-CD8 ${ }^{-} \mathrm{T}$ cells, and $\gamma \delta \mathrm{T}$ cells. Among them, regulatory $\mathrm{T}$ cells, or Tregs, identified by the expression of CD4, CD25, and Foxp3 are the most studied and are probably the major players in the maintenance of immune tolerance and homeostasis $(129,130)$.

Two main subtypes of Tregs have been described. Natural Tregs generated in the thymus, constitute $5-10 \%$ of the $\mathrm{CD}^{+}$ lymphocytes in the peripheral blood (131). Induced regulatory $\mathrm{T}$ cells develop in periphery after antigen exposure and stimulation by appropriate signals as TGF- $\beta$ (132). Both lineages share similar functional features. Tregs suppress immune-mediated responses by several mechanisms: they inhibit production of IFN $\gamma$ and IL-17, produce IL-10 to enforce the anti-inflammatory cytokine pathway $(133,134)$, induce production of small anti-inflammatory molecules like adenosine (135) and directly interact with and induce apoptosis of Th1 cells via the galectin9-TIM-3 pathways (136). Moreover, Tregs have been described as capable of modulating other cells of the adaptive immune system, including $\mathrm{CD}^{+} \mathrm{T}$ cells and $\mathrm{B}$ cells, and able to interact with many components of the innate immune system, 
such as dendritic cells, macrophages, neutrophils, and $\gamma \delta \mathrm{T}$ cells (137).

In human pathology, genetically determined severe loss of function of Tregs causes multiorgan autoimmune disease such as the autoimmune polyendocrinopathy-candidiasis-ectodermal dystrophy (APECED) caused by mutations of the gene AIRE (138) or the immunodysregulation, polyendocrinopathy, enteropathy, X-linked (IPEX) syndrome, a catastrophic and often lethal systemic disease secondary to critical dysfunction of Foxp3 (139).

A putative role of impaired T-cells regulatory function in the pathogenesis of multifactorial autoimmune diseases was extensively investigated, but is still debated. Tregs are a very heterogeneous population and are able to change phenotype according to the local cytokine environment (140). Moreover, the number of circulating Tregs is highly variable during an inflammatory process, they move to the target organ and their blood count decreases as demonstrated during acute rejection in transplanted patients (141).

In autoimmune hepatitis Tregs function was accurately investigated, both in adults than in pediatric patients, by the group of the King's College. In the early studies a numerical and functional deficiency of Tregs was suggested; they were decreased in number and with defective expansion under stimulation (142), the expression of Foxp3 was lower, co-culture with effectors cells lead to decreased TGF $\beta$ and increased IL4 secretion and spontaneous apoptosis of $\mathrm{CD} 4^{+} \mathrm{CD} 25^{-}$was defective in pediatric patients (143). In adult patients the defect in immunoregulation was more complex involving Tregs but also other regulatory cell populations (144). The more recent studies focused on CD39+ ${ }^{+}$Tregs producing adenosine and found multiple defects, both in their numbers and functions (145). Moreover, Tregs showed a decreased capability to produce IL10 and suppress target cell proliferation (146). Despite these results, recent studies on adult patients with $\mathrm{AIH}$ failed to confirm a functional defect in Tregs compartment. They were numerically comparable to healthy subjects in both blood and liver, and exhaustive in vitro functional studies were fully normal $(147,148)$. In any case, the possibility to treat AIH potentiating the immunoregulatory properties of endogenous regulatory cells generated great enthusiasm because of the potential ultraselective action with virtual absence of adverse effects and as it offers the chance to achieve long-term tolerance to liver autoantigens. Many approaches are theoretically possible.

\section{Ex vivo Expanded Tregs. Adoptive Immunotherapy}

Autologous ex vivo expanded Tregs could represent an elegant approach but a few issues make this approach a tough challenge. First, Tregs are activated via the TCR receptor and, as effector cells, are peptide-specific. This means that pathogenic autoantigens must be known and available for manipulation. Second, infused cells must find the way to correctly localize into the target organ as they act with short-range mechanisms (direct interaction or paracrine signals). Third and lastly, manipulation of these cells must take place according to strict good manufacturing practices (GMP) to ensure high purity of the product. This is very expensive and requires a complex organization, and availability of GMP-compliant reagents or intermediate products could restrict the feasibility of innovative techniques.

Tregs can be isolated from circulating mononuclear cells (PBMCs) according to the most appropriate markers set, in most recent studies $\mathrm{CD} 4^{+} / \mathrm{CD} 25^{\text {high }} / \mathrm{CD} 127^{-/ \text {low }}$, then activated and expanded by non-specific antigen stimulation, usually coactivation of CD3 and CD28 in presence of IL-2. This method leads to a polyclonal Tregs population (149). In the animal model cited above (15) adoptive transfer of ex vivo expanded Tregs in mice with AIH restored peripheral tolerance to the target antigen formimidoyltransferase cyclodeaminase and induced remission of $\mathrm{AIH}(150)$. In this model $\mathrm{CD} 4^{+} \mathrm{CD} 25^{+} \mathrm{FoxP}^{+}$Tregs from xenoimmunized mice expressed high levels of the liver-homing chemokine receptor CXCR3, the cognate receptor of CXCL9 and CXCL9 (151), allowing a correct localization of Treg into the target organ.

Although polyclonal Tregs are less effective in controlling autoimmune responses than monoclonal antigen-specific Tregs, little clinical experience exists. The only concluded clinical study in liver pathology involved 10 adult liver-transplanted patients. A co-culture of donor with recipient lymphocytes in the presence of co-stimulatory signals generated a population enriched with polyclonal Tregs, partially matched with donor antigens. Administration of this product allowed tapering followed by discontinuation of immunosuppressive agents within 18 months in 7 out of 10 patients (152). A Chinese phase 1 study using polyclonally expanded Tregs is ongoing in $\mathrm{AIH}$ patients resistant to conventional treatment (Table 2). Besides liver diseases, polyclonal Tregs HLA-matched or partially matched were clinically tested to treat graft vs. host disease in allogenic stem cell transplantation with some positive effects (153-155) and in therapy of Type 1 diabetes both in adults and in children (156, 157). These results encouraged the research for more specific Tregs populations. A proof of concept that autoantigensspecific Tregs are able to revert established autoimmune diseases was obtained in animal model of type 1 diabetes $(158,159)$ but also in humans antigen-specific regulatory $\mathrm{T}$ cells generated by $\mathrm{T}$ cell receptor gene transfer can be obtained (160).

A promising simple methodology to obtain a therapeutic product with high percentage of autoantigen-specific Tregs is based on surface markers such as latency-associated peptide (LAP) and glycoprotein A repetitions predominant (GARP) that are expressed by stimulated Tregs but not by effectors Tcells which conversely express CD154. Selection and expansion of CD4+ CD25+ CD127-/low GARP+/LAP+ CD154- cells increases the Tregs cell purity to over 90\%, most of them already activated against the ongoing autoimmune disease (161).

In transplantation medicine various methods have been developed to obtain the so-called donor alloantigen reactive Tregs (darTregs), a mixture of polyclonal recipient derived Tregs enriched in cells activated by donor alloantigens (162, 163). DarTregs are currently evaluated in several phase I or II trials but unfortunately this concept can't be exported in the setting of autoimmune diseases.

The technology of chimeric antigen receptor (CAR) $\mathrm{T}$ cells, developed in oncology, might theoretically be adapted 
to potentiate an antigen-specific regulatory effect. This methodology consists in transducing $\mathrm{T}$ cells with a chimeric protein made with an extracellular antigen binding domains, properly selected, joined to transmembrane and intracellular co-stimulatory domains. Activation of CAR by the antigen causes an intracellular signal that overrides the original signaling via the TCR. In oncology CARs recognizing tumor antigens are transduced into autologous effector Tcells (164) but CARs can also be transduced in $\mathrm{T}$ cells with regulatory phenotype that, once expanded, represents a monoclonal antigen specific Tregs population (165). CAR Tregs against donor HLA were more effective than polyclonal Tregs to improve rejection in a human skin xenograft transplant model (166). The production of monoclonal liver-specific CARs, however, requires the knowledge of pathogenetic antigens, which is the case for type 2 AIH but not for type 1 AIH or PSC.

A different approach to generate T-regs specific for CYP2D6 immunodominant regions was described in 2011 by Longhi et al. (167). In this model Tregs isolated from patients carriers of predisposing HLA-DR7 and/or HLA-DR3 alleles were cocultured with CYP2D6-peptide-loaded semi-mature DCs. The final product, an oligoclonal mixture of Tregs reacting against CYP2D6 epitopes, was able to suppress in vitro expansion of effector cells (167). Although promising, these results did not lead to application in clinical trials.

\section{In vivo Stimulation of Tregs: The IL-2 Pathway}

IL-2 is a key factor of the immune system cytokine network. IL-2 is essential to promote response of effector cells but also expansion, survival, and maintenance of regulatory function of Tregs. This dual effect is mediated by the complex structure of the receptor (IL-2R). The high affinity trimeric form is composed of the subunit IL-2R $\alpha$ (CD25) and the subunits IL-2R $\beta$ and IL$2 \mathrm{R} \gamma$. Both Tregs and activated CD4 cells may express this trimeric form (Figure 2) while CD8 and NK cells bear low affinity dimeric form that lacks CD25 (168). IL2RA deficient mice shows a complete deficiency of regulatory $\mathrm{T}$ cells and develop multiorgan lethal autoimmune disease involving skin, intestine, lung, and liver (169). In mature immune systems, however, effects depend on IL-2 local concentration: exogenous IL-2 typically amplifies effector T cells response but preferential activation of high affinity receptor by low dose IL-2 determine a prevalent suppressor effect (168). A few clues suggest an association between IL2 signal deregulation and autoimmune liver diseases. GWAS studies indicated an association of polymorphism of IL-2 and IL2Ra with PBC and PSC but not with AIH (170). Liver-derived lymphocytes from patients with PSC show reduced expression of the IL-2 receptor (171). In AIH patients, baseline and under therapy IL-2 serum levels seems lower than controls (172) and children with higher baseline levels of IL-2 more easily achieve biochemical remission (173).

Low dose IL-2 therapy could be a good tool to potentiate in vivo Tregs pool and to stimulate suppressor function. Clinical studies have already shown positive effects in patients with different autoimmune disease including SLE and diabetes (174,
175) and an ongoing trial is enrolling patients with $\mathrm{AIH}$ (Table 2) despite the finding of a possible defective regulatory T-cell responsiveness to IL-2 (146). To date only two patients with AIH have been treated with low dose IL-2 as rescue therapy: even if only one patient reached remission, in both blood Tregs number increased after therapy (176). Although in vitro studies of liver explants showed that low dose IL-2 increases activity of Tregs but not of Teff, clinical response is not completely predictable, and a worsening of disease has been observed in patients with diabetes (177). For these reasons another attractive approach to up regulate in vivo Tregs function through IL-2 stimulation is currently under investigation. IL-2 is a molecule with high conformational flexibility; this property can be used to selectively target Tregs. A recently developed fully human antibody stabilizes IL-2 in a conformation that preferentially potentiates Tregs activity. In a mouse model of autoimmune encephalomyelitis it reduced disease severity and induced remission of type 1 diabetes in the NOD mouse (178).

\section{OTHER THERAPEUTIC OPTIONS}

Mesenchymal stem cells (MSC) are a lineage of multipotent cells that can differentiate in all mesenchymal-derived cells as osteoblasts or adipocytes. They can be isolated from bone marrow, umbilical cord blood but also by peripheral tissue. MSC suppress differentiation of naïve T Cells into effector cells (Th1, Th17) promoting maturation toward Treg phenotype. They counteract proliferation of $\mathrm{NK}$ and $\mathrm{CD} 8^{+}$cells and they induce tolerogenic phenotype in dendritic cells. This action is mainly mediated by humoral signals such as TGF $\beta$, IL-10, nitric oxide and many others and are not dependent from direct contact with target cells, thus a correct homing of these cells is less important (179).

First implementation of MSC therapy in autoimmune liver disease involved patients with PBC. In two separate pilot studies a total of 17 patients were treated with positive results, their quality of life substantially improved. More importantly, the safety profile was excellent $(180,181)$. Two studies on large cohorts of AIH patients are currently ongoing (Table 2).

Erythropoietin is a well-known molecule produced by the kidney in response to hypoxia that stimulates bone marrow to produce red blood cells. Recently it was recognized to have immune-modulating and tissue-protective effects. CD4+ and CD8+ $\mathrm{T}$ cells express EPO receptor and experimental data showed that EPO has a direct inhibitory effect on effector/memory $\mathrm{T}$ cells, while it promotes formation of regulatory $\mathrm{T}$ cells (182). A pre-phase 1 study is ongoing to evaluate change of Tregs number and cytokines profile in the blood of AIH patients after a single administration of EPO (Table 2).

\section{INTESTINAL MICROBIOME AND DIETARY INTERVENTIONS}

The growing knowledge about the role of intestinal microbiome in almost every human physiological pathway is probably the 
most relevant advance in medical research in recent years. The human gut hosts $10-11$ trillion bacteria comprising $500-$ 1500 different species from four major phyla: Actinobacteria, Firmicutes, Proteobacteria, and Bacteroidetes (183). The interplay between intestinal innate and adaptive immune system and bacteria can influence systemic immune response, trigger autoimmunity or determine tolerance against bacterial or alimentary xenoantigens. Main factors deciding the outcome of this interaction are intestinal barrier permeability, genetic host variability and composition of the microbiome (184). Activated lymphocytes against products that mimic normal self-proteins, bacterial antigens or simply cytokines (intestinal inflammasome) generated in the intestinal tract may translocate in systemic circulation and produce peripheral immune-mediated tissue damage (185). Variation of the composition of the microbiome has been associated with several systemic immune-mediated diseases, including type 1 diabetes (186), inflammatory bowel disease (187) and rheumatoid arthritis (188) but also with PSC and AIH $(189,190)$. In a novel mouse model of AIH, active disease was associated with reduced diversity and total load of intestinal bacteria (191). Liver-infiltrating lymphocytes in PSC include $\mathrm{A} 4 \beta 7^{+} \mathrm{CCR} 9^{+} \mathrm{CD} 8^{+}$memory $\mathrm{T}$ cells activated in the gut and recruited to the liver by aberrant expression of the gut-specific chemokine CCL25 on the hepatic endothelium (192). Microbiome composition may also confer protection against autoimmune diseases and this property is transmissible to other individuals. It is found to differ in Male and female NOD mice, and this characteristic is lost after male castration. Female NOD mice are more prone to develop type 1 diabetes than male. Colonization of immature female NOD mice with the intestinal microflora from mature male NOD mice protects from diabetes (193). So far incomplete comprehension of multiple factors affecting the microflora composition do not allow translation to clinical practice, but a huge amount of data have already been accumulated, for instance, by the Humane Microbiome Project, and initial practical results are conceivable in a near future. Specific aspects, however, are currently being investigated. Toll-like receptor 4 (TLR4) is a recognition receptor for bacterial peptides expressed on hepatocytes, liver sinusoidal endothelial cells, Kupffer cells and hepatic stellate cells. As the other toll-receptor family members expressed by enterocytes, according to quality and intensity of stimulating bacterial components, it can induce tolerance or promote immune activation and liver fibrosis. JKB-122 is a TLR4 antagonist that demonstrated ability to reduce hepatocyte necrosis and potentiate effect of low dose prednisolone in an experimental mouse model for liver injury (194). A pilot clinical trial is currently underway (Table 2).

Microflora composition is influenced by a number of variables, among that alimentary behavior is the most easy to manipulate. High sodium diet has detrimental effects on immunological homeostasis by several mechanisms. Indirect effects are mediated by the change of composition of microbiome, higher sodium concentration decrease number of Lactobacillus spp that have the property of hamper Th17 polarization trough the increase of indole production, a metabolite of tryptophan (195). On the other side, high sodium concentration enhances
Th17 differentiation trough the induction of osmosensitive nuclear factor of activated T cells (NFAT) 5 that finally leads to potentiate activity of IL-23 receptor and of the mTOR pathway (196). A trial on the effects of low sodium diet is currently recruiting patients with $\mathrm{AIH}$ (Table 2). Another study on the effects of a high fiber, high protein diet in AIH patients was recently concluded but results are pending. The rationale of this trial is that dietary fibers are fermented by gut microbiota to short-chain fatty acids (SCFA) as propionate, acetate or butyrate. SCFA exert multiple regulatory activities, increase colonic Tregs number, but also increase FOXP3 expression and secretion of anti-inflammatory IL-10 (197). This diet already showed positive effects on a mouse model of $\mathrm{AIH}$ in terms of disease activity, higher Treg/Th17 cell ratio and decrease of intestinal permeability (198). Enhanced intestinal permeability with elevated blood concentrations of lipopolysaccharides was found in a population of Chinese patients with AIH (199).

\section{CONCLUSIONS}

Autoimmune hepatitis is a complex disease. The clinical onset can be widely varied, and ranges between hyper-acute hepatitis with liver failure to chronic, unapparent disease with mild, fluctuating increase of liver enzymes, the latter usually leading to a late diagnosis with severe, established fibrosis. Besides typical cases with prominent hypergammaglobulinemia and high-titer autoantibodies, diagnosis is usually challenging: autoantibodies may be absent in up to $20 \%$ of cases and liver histology may show inconclusive pictures, overlapping with features of bystander hepatitis, which is very common in several systemic diseases. The scoring systems proposed so far are more useful for research purposes than for clinical use, especially in children. Once diagnosis is made, the short-term management is often simple. Currently available treatments induce remission in almost the totality of cases and clinicians might have the erroneous feeling that the patient is cured. Indeed, the longterm management of the disease is the most challenging task. Once biochemical remission is achieved, there are no reliable biomarkers of underlying activity to guide the tapering of immunosuppression and to estimate the risk of relapse at suspension of therapy. Current available drugs are able to avoid further liver damage but do not cure the imbalance of the immune system that is the root of the disease. A few patients achieve spontaneous desensitization against liver antigens during conventional therapy and do not relapse at suspension but the large majority of them experiences an extenuating sequence of relapses and often serious adverse effects of steroid therapy that finally compromise the compliance, especially in female adolescents. The worse situation to face is an uncontrolled disease in an adolescent with a long history of disease and multiple relapses with no second line treatment remaining to propose.

The ideal therapy should be enough selective to contrast immunomediated liver damage while preserving or potentiating the ability to develop permanent tolerance vs. pathogenic autoantigens. Indeed, the inadequate knowledge 
of the autoantigens involved in the pathogenesis of $\mathrm{AIH}$ constitutes a major obstacle for research. Recent progress in molecular biology, however, made available a number of potential new therapeutic strategies, some of them already tested in small group of patients or, more frequently, in other autoimmune disease (Table 1). Future advancements depend on the availability of large registries of patients

\section{REFERENCES}

1. Maggiore G, Nastasio S, Sciveres M. Juvenile autoimmune hepatitis: spectrum of the disease. World J Hepatol. (2014) 6:464-76. doi: 10.4254/wjh.v6.i7.464

2. Gregorio GV, Portmann B, Reid F, Donaldson PT, Doherty DG, McCartney $\mathrm{M}$, et al. Autoimmune hepatitis in childhood: a 20-year experience. Hepatology. (1997) 25:541-7. doi: 10.1002/hep.510250308

3. Deneau M, Jensen MK, Holmen J, Williams MS, Book LS, Guthery SL. Primary sclerosing cholangitis, autoimmune hepatitis and overlap in Utah children: epidemiology and natural history. Hepatology. (2013) 58:1392-400. doi: 10.1002/hep.26454

4. Maggiore G, Bernard O, Homberg JC, Hadchouel M, Alvarez F, Hadchouel P., et al. Liver disease associated with anti-liver-kidney microsome antibody in children. J Pediatr. (1986) 108:399-404. doi: 10.1016/S0022-3476(86)80880-0

5. Maggiore G, Veber F, Bernard O, Hadchouel M, Homberg JC, Alvarez F., et al. Autoimmune hepatitis associated with anti-actin antibodies in children and adolescents. J Pediatr Gastroenterol Nutr. (1993) 17:376-81. doi: 10.1097/00005176-199311000-00007

6. Maggiore G, Porta G, Bernard O, Hadchouel M, Alvarez F, Homberg JC., et al. Autoimmune hepatitis with initial presentation as acute hepatic failure in young children. $J$ Pediatr. (1990) 116:280-2. doi: 10.1016/S0022-3476(05)82892-6

7. Caprai S, Vajro P, Ventura A, Sciveres M, Maggiore G, SIGENP Study Group for Autoimmune Liver Disorders in Celiac Disease. Autoimmune liver disease associated with celiac disease in childhood: a multicenter study. Clin Gastroenterol Hepatol. (2008) 6:803-6. doi: 10.1016/j.cgh.2007.12.002

8. Routes JM, Verbsky JW. Immunodeficiency presenting as an undiagnosed disease. Pediatr Clin North Am. (2017) 64:27-37. doi: 10.1016/j.pcl.2016.08.007

9. Mieli-Vergani G, Vergani D, Baumann U, Czubkowski P, Debray D, Dezsofi A., et al. Diagnosis and management of pediatric autoimmune liver disease: ESPGHAN hepatology committee position statement. J Pediatr Gastroenterol Nutr. (2018) 66:345-60. doi: 10.1097/MPG.0000000000001801

10. Vergani D, Alvarez F, Bianchi FB, Cançado EL, Mackay IR, Manns MP., et al. Liver autoimmune serology: a consensus statement from the committee for autoimmune serology of the International Autoimmune Hepatitis Group. $J$ Hepatol. (2004) 41:677-83. doi: 10.1016/j.jhep.2004.08.002

11. Bridoux-Henno L, Maggiore G, Johanet C, Fabre M, Vajro P, Dommergues JP., et al. Features and outcome of autoimmune hepatitis type 2 presenting with isolated positivity for anti-liver cytosol antibody. Clin Gastroenterol Hepatol. (2004) 2:825-30. doi: 10.1016/S1542-3565(04)00354-4

12. Gueguen M, Meunier-Rotival M, Bernard O, Alvarez F. Anti-liver kidney microsome antibody recognizes a cytochrome P450 from the IID subfamily. J Exp Med. (1988) 168:801-6. doi: 10.1084/jem.168.2.801

13. Lapierre P, Hajoui O, Homberg JC, Alvarez F. Formiminotransferase cyclodeaminase is an organ-specific autoantigen recognized by sera of patients with autoimmune hepatitis. Gastroenterology. (1999) 116:643-9. doi: 10.1016/S0016-5085(99)70186-1

14. Muratori L, Parola M, Ripalti A, Robino G, Muratori P, Bellomo G., et al. Liver/kidney microsomial antibody type 1 targets CYP2D6 on hepatocyte plasma membrane. Gut. (2000) 46:553-61. doi: 10.1136/gut.46.4.553

15. Lapierre P, Djilali-Saiah I, Vitozzi S, Alvarez F. A murine model of type 2 autoimmune hepatitis: xenoimmunization with human antigens. Hepatology. (2004) 39:1066-74. doi: 10.1002/hep.20109 that may be the basis for international collaborative clinical trials.

\section{AUTHOR CONTRIBUTIONS}

MS: conceptualization, writing-original draft. SN and GM: validation, writing-review, and editing.

16. Maggiore G, Socie G, Sciveres M, Roque-Afonso AM, Nastasio S, Johanet C., et al. Seronegative autoimmune hepatitis in children: spectrum of disorders. Dig Liver Dis. (2016) 48:785-91. doi: 10.1016/j.dld.2016.03.015

17. Alvarez F, Berg PA, Bianchi FB, Bianchi L, Burroughs AK, Cancado EL, et al. International Autoimmune Hepatitis Group Report: review of criteria for diagnosis of autoimmune hepatitis. J Hepatol. (1999) 131:929-38.

18. Ebbeson RL, Schreiber RA. Diagnosing autoimmune hepatitis in children: is the International Autoimmune Hepatitis Group scoring system useful? Clin Gastroenterol Hepatol. (2004) 2:935-40. doi: 10.1016/S1542-3565(04)00396-9

19. Hennes EM, Zeniya M, Czaja AJ, Parés A, Dalekos GN, Krawitt EL., et al. Simplified criteria for the diagnosis of autoimmune hepatitis. Hepatology. (2008) 48:169-76. doi: 10.1002/hep.22322

20. Hiejima E, Komatsu $H$, Sogo $T$, Inui A, Fujisawa $T$. Utility of simplified criteria for the diagnosis of autoimmune hepatitis in children. $J$ Pediatr Gastroenterol Nutr. (2011) 52:470-3. doi: 10.1097/MPG.0b013e3181 fcle $0 \mathrm{~b}$

21. Miao Q, Bian Z, Tang R, Zhang H, Wang Q, Huang S., et al. Emperipolesis mediated by CD8 T cells is a characteristic histopathologic feature of autoimmune hepatitis. Clin Rev Allergy Immunol. (2015) 48:226-35. doi: 10.1007/s12016-014-8432-0

22. Murray-Lyon IM, Stern RB, Williams R. Controlled trial of prednisone and azathioprine in active chronic hepatitis. Lancet. (1973) 1:735-7. doi: 10.1016/S0140-6736(73)92125-9

23. Maggiore G, Bernard O, Hadchouel M, Hadchouel P, Odievre M, Alagille D. Treatment of autoimmune chronic active hepatitis in childhood. J Pediatr. (1984) 104:839-44. doi: 10.1016/S0022-3476(84)80477-1

24. Vegnente A, Larcher VF, Mowat AP, Portmann B, Williams R. Duration of chronic active hepatitis and the development of cirrhosis. Arch Dis Child. (1984) 59:330-5. doi: 10.1136/adc.59.4.330

25. Mieli-Vergani G, Vergani D. Autoimmune paediatric liver disease. World J Gastroenterol. (2008) 14:3360-7. doi: 10.3748/wjg.14.3360

26. Vitfell-Pedersen J, Jørgensen MH, Müller K, Heilmann C. Autoimmune hepatitis in children in Eastern Denmark. J Pediatr Gastroenterol Nutr. (2012) 55:376-9. doi: 10.1097/MPG.0b013e3182602b20

27. Cuarterolo ML, Ciocca ME, López SI, de Dávila MT, Alvarez F. Immunosuppressive therapy allows recovery from liver failure in children with autoimmune hepatitis. Clin Gastroenterol Hepatol. (2011) 9:145-9. doi: 10.1016/j.cgh.2010.10.013

28. Kerkar CN, Annunziato RA, Foley L, Schmeidler J, Rumbo C, Emre $\mathrm{S}$, et al. Prospective analysis of nonadherence in autoimmune hepatitis: a common problem. J Pediatr Gastroenterol Nutr. (2006) 43:629-34. doi: 10.1097/01.mpg.0000239735.87111.ba

29. Alvarez F, Ciocca M, Canero-Velasco C, Ramonet M, de Davila MT, Cuarterolo $\mathrm{M}$, et al. Short-term cyclosporine induces a remission of autoimmune hepatitis in children. J Hepatol. (1999) 30:222-7. doi: 10.1016/S0168-8278(99)80065-8

30. Debray D, Maggiore G, Girardet JP, Mallet E, Bernard O. Efficacy of cyclosporin A in children with type 2 autoimmune hepatitis. J Pediatr. (1999) 135:111-4. doi: 10.1016/S0022-3476(99)70339-2

31. Hyams JS, Ballow M, Leichtner AM. Cyclosporine treatment of autoimmune chronic active hepatitis. Gastroenterology. (1987) 93:890-3. doi: 10.1016/0016-5085(87)90454-9

32. Czaja AJ. Diagnosis and management of autoimmune hepatitis: current status and future directions. Gut Liver. (2016) 10:177-203. doi: $10.5009 /$ gnl15352 
33. Cuarterolo M, Ciocca M, Velasco CC, Ramonet M, González T, López S., et al. Follow-up of children with autoimmune hepatitis treated with cyclosporine. J Pediatr Gastroenterol Nutr. (2006) 43:635-9. doi: 10.1097/01.mpg.0000235975.75120.38

34. Sciveres M, Caprai S, Palla G, Ughi C, Maggiore G. Effectiveness and safety of ciclosporin as therapy for autoimmune diseases of the liver in children and adolescents. Aliment Pharmacol Ther. (2004) 19:209-17. doi: 10.1046/j.1365-2036.2003.01754.x

35. Nastasio S, Sciveres M, Matarazzo L, Malaventura C, Cirillo F, Riva S, et al. Long-term follow-up of children and young adults with autoimmune hepatitis treated with cyclosporine. Dig Liver Dis. (2018) 51:712-8. doi: 10.1016/j.dld.2018.10.018

36. Zizzo AN, Valentino PL, Shah PS, Kamath BM. Second-line agents in pediatric patients with autoimmune hepatitis: a systematic review and meta-analysis. J Pediatr Gastroenterol Nutr. (2017) 65:6-15. doi: 10.1097/MPG.0000000000001530

37. Nastasio S, Sciveres M, Matarazzo L, Maggiore G. Old and new treatments for pediatric autoimmune hepatitis. Curr Pediatr Rev. (2018) 14:187-95. doi: 10.2174/1573396314666180516130314

38. Woynarowski M, Nemeth A, Baruch Y, Koletzko S, Melter M, Rodeck B., et al. Budesonide versus prednisone with azathioprine for the treatment of autoimmune hepatitis in children and adolescents. J Pediatr. (2013) 163:1347-53. doi: 10.1016/j.jpeds.2013.05.042

39. Mieli-Vergani G, Vergani D. Budesonide for juvenile autoimmune hepatitis? Not yet J Pediatr. (2015) 163:1246-8. doi: 10.1016/j.jpeds.2013.06.064

40. Ytting $\mathrm{H}$, Larsen FS. Everolimus treatment for patients with autoimmune hepatitis and poor response to standard therapy and drug alternatives in use, Scand. J. Gastroenterol. (2015) 50:1025-31. doi: 10.3109/00365521.2014.998271

41. Chatrath HL, Allen TD. Boyer Use of sirolimus in the treatment of refractory autoimmune hepatitis. Am J Med. (2014) 127:1128-31. doi: 10.1016/j.amjmed.2014.06.016

42. Kumari N, Kathuria R, Srivastav A, Krishnani N, Poddar U, Yachha SK. Significance of histopathological features in differentiating autoimmune liver disease from non-autoimmune chronic liver disease in children. Eur J Gastroenterol Hepatol. (2013) 25:333-7. doi: 10.1097/MEG.0b013e32835a68a1

43. Czaja AJ. Rapidity of treatment response and outcome in type 1 autoimmune hepatitis. J Hepatol. (2009) 51:161-7. doi: 10.1016/j.jhep.2009.02.026

44. Czaja AJ, Menon KV, Carpenter HA. Sustained remission after corticosteroid therapy for type 1 autoimmune hepatitis: a retrospective analysis. Hepatology. (2002) 35:890-7. doi: 10.1053/jhep.2002.32485

45. Montano-Loza AJ, Carpenter HA, Czaja AJ. Predictive factors for hepatocellular carcinoma in type 1 autoimmune hepatitis. Am J Gastroenterol. (2008) 103:1944-51. doi: 10.1111/j.1572-0241.2008.01922.x

46. Czaja AJ. Emerging therapeutic biomarkers of autoimmune hepatitis and their impact on current and future management. Expert Rev Gastroenterol Hepatol. (2018) 12:547-64. doi: 10.1080/17474124.2018.1453356

47. Ambros V. The functions of animal microRNAs. Nature. (2004) 431:350-5. doi: $10.1038 /$ nature 02871

48. Yamaura Y, Tatsumi N, Takagi S, Tokumitsu S, Fukami T, Tajiri K, et al. Serum microRNA profiles in patients with chronic hepatitis B, chronic hepatitis C, primary biliary cirrhosis, autoimmune hepatitis, nonalcoholic steatohepatitis, or drug-induced liver injury. Clin Biochem. (2017) 50:1034-9. doi: 10.1016/j.clinbiochem.2017.08.010

49. Migita K, Komori A, Kozuru H, Jiuchi Y, Nakamura M, Yasunami M, et al. Circulating microRNA profiles in patients with type-1 autoimmune hepatitis. PLoS ONE. (2015) 10:e0136908. doi: 10.1371/journal.pone. 0136908

50. Halasz T, Horvath G, Par G, Werling K, Kiss A, Schaff Z, et al. miR-122 negatively correlates with liver fibrosis as detected by histology and FibroScan. World J Gastroenterol. (2015) 21:7814-23. doi: 10.3748/wjg.v21.i25.7814

51. McKinney EF, Lee JC, Jayne DR, Lyons PA, Smith KG. T-cell exhaustion, co-stimulation and clinical outcome in autoimmunity and infection. Nature. (2015) 523:612-6. doi: 10.1038/nature14468

52. Mataki N, Kikuchi K, Kawai T, Higashiyama M, Okada Y, Kurihara $\mathrm{C}$, et al. Expression of PD-1, PD-L1, and PD-L2 in the liver in autoimmune liver diseases. Am J Gastroenterol. (2007) 102:302-12. doi: 10.1111/j.1572-0241.2006.00948.x

53. Matsumoto K, Miyake Y, Matsushita H, Ohnishi A, Ikeda F, Shiraha H, et al. Anti-programmed cell death-1 antibody as a new serological marker for type 1 autoimmune hepatitis. J Gastroenterol Hepatol. (2014) 29:110-5. doi: 10.1111/jgh.12340

54. Miyake Y, Yamamoto K, Matsushita H, Abe M, Takahashi A, Umemura T, et al. Multicenter validation study of anti-programmed cell death-1 antibody as a serological marker for type 1 autoimmune hepatitis. Hepatol Res. (2014) 44:1299-307. doi: 10.1111/hepr.12305

55. Aarslev K, Dige A, Greisen SR, Kreutzfeldt M, Jessen N, Vilstrup H, et al. Soluble programmed death-1 levels are associated with disease activity and treatment response in patients with autoimmune hepatitis. Scand J Gastroenterol. (2017) 52:93-9. doi: 10.1080/00365521.2016.1233576

56. Calandra T, Bernhagen J, Metz CN, Spiegel LA, Bacher M, Donnelly T, et al. MIF as a glucocorticoid-induced modulator of cytokine production. Nature. (1995) 377:68-71. doi: 10.1038/377068a0

57. Assis DN, Leng L, Du X, Zhang CK, Grieb G, Merk M., et al. The role of macrophage migration inhibitory factor in autoimmune liver disease. Hepatology. (2014) 59:580-91. doi: 10.1002/hep.26664

58. Assis DN, Takahashi H, Leng L, Zeniya M, Boyer JL, Bucala R, et al. A macrophage migration inhibitory factor polymorphism is associated with autoimmune hepatitis severity in US and Japanese patients. Dig Dis Sci. (2016) 61:3506-12. doi: 10.1007/s10620-016-4322-z

59. Kristiansen M, Graversen JH, Jacobsen C, Sonne O, Hoffman HJ, Law SK, et al. Identification of the haemoglobin scavenger receptor. Nature. (2001) 409:198-201. doi: 10.1038/35051594

60. Gronbaek H, Kreutzfeldt M, Kazankov K, Jessen N, Sandahl T, HamiltonDutoit S, et al. Single-centre experience of the macrophage activation marker soluble (s)CD163 -associations with disease activity and treatment response in patients with autoimmune hepatitis. Aliment Pharmacol Ther. (2016) 44:1062-70. doi: 10.1111/apt.13801

61. Kazankov K, Barrera F, Moller HJ, Bibby BM, Vilstrup H, George J, et al. Soluble CD163, a macrophage activation marker, is independently associated with fibrosis in patients with chronic viral hepatitis B and C. Hepatology. (2014) 60:521-30. doi: 10.1002/hep.27129

62. Schneider P, MacKay F, Steiner V, Hofmann K, Bodmer JL, Holler N, et al. BAFF, a novel ligand of the tumor necrosis factor family, stimulates B cell growth. J Exp Med. (1999) 189:1747. doi: 10.1084/jem.189.11.1747

63. Migita K, Abiru S, Maeda Y, Nakamura M, Komori A, Ito M, et al. Elevated serum BAFF levels in patients with autoimmune hepatitis. Hum Immunol. (2007) 68:586-91. doi: 10.1016/j.humimm.2007.03.010

64. Cookson S, Constantini PK, Clare M, Underhill JA, Bernal W, Czaja $\mathrm{AJ}$, et al. Frequency and nature of cytokine gene polymorphisms in type 1 autoimmune hepatitis. Hepatology. (1999) 30:851-6. doi: 10.1002/hep.510300412

65. Czaja AJ, Cookson S, Constantini PK, Clare M, Underhill JA, Donaldson PT. Cytokine polymorphisms associated with clinical features and treatment outcome in type 1 autoimmune hepatitis. Gastroenterology. (1999) 117:64552. doi: 10.1016/S0016-5085(99)70458-0

66. Akberova D, Kiassov AP, Abdulganieva D. Serum cytokine levels and their relation to clinical features in patients with autoimmune liver diseases. $J$ Immunol Res. (2017) 2017:9829436. doi: 10.1155/2017/9829436

67. Qin B, Li J, Liang Y, Yang Z, Zhong R. The association between Cytotoxic $\mathrm{T}$ lymphocyte associated antigen-4, Fas, tumor necrosis factor- $\alpha$ gene polymorphisms and autoimmune hepatitis: a meta-analysis. Dig Liver Dis Jun. (2014) 46:541-8. doi: 10.1016/j.dld.2014.02.003

68. Weiler-Normann C, Schramm C, Quaas A, Wiegard C, Glaubke C, Pannicke $\mathrm{N}$., et al. Infliximab as a rescue treatment in difficult-to-treat autoimmune hepatitis. J Hepatol. (2013) 58:529-34. doi: 10.1016/j.jhep.2012.11.010

69. Fujii K, Rokutanda R, Osugi Y, Koyama Y, Ota T. Adult-onset Still's disease complicated by autoimmune hepatitis: successful treatment with infliximab. Intern Med. (2012) 51:1125-8. doi: 10.2169/internalmedicine.51.6824

70. Rajanayagam J, Lewindon PJ. Infliximab as rescue therapy in paediatric autoimmune hepatitis. J Hepatol. (2013) 59:908-9. doi: 10.1016/j.jhep.2013.05.046

71. Nedelkopoulou N, Vadamalayan B, Vergani D, Mieli-Vergani G. Anti-TNFa treatment in children and adolescents with combined inflammatory bowel 
disease and autoimmune liver disease. J Pediatr Gastroenterol Nutr. (2018) 66:100-5. doi: 10.1097/MPG.0000000000001759

72. Atzeni F, Talotta R, Salaffi F, Cassinotti A, Varisco V, Battellino M, et al. Immunogenicity and autoimmunity during anti-TNF-therapy. Autoimmun Rev. (2013) 13:703-8. doi: 10.1016/j.autrev.2012.10.021

73. Chen X, Oppenheim JJ. Contrasting effects of TNF and anti-TNF on activation of effector $\mathrm{T}$ cells and regulatory $\mathrm{T}$ cells in autoimmunity. FEBS Lett. (2011) 585:3611-8. doi: 10.1016/j.febslet.2011.04.025

74. Zheng L, Fisher G, Miller RE, Peschon J, Lynch DH, Lenardo MJ. Induction of apoptosis in mature T cells by tumour necrosis factor. Nature. (1995) 377:348-51. doi: 10.1038/377348a0

75. Lopetuso LR, Mocci G, Marzo M, D’Aversa F, Rapaccini GL, Guidi $L$, et al. Harmful effects and potential benefits of Anti-Tumor Necrosis Factor (TNF)- $\alpha$ on the liver. Int J Mol Sci. (2018) 19:E2199. doi: $10.3390 / \mathrm{ijms} 19082199$

76. Ricciuto A, Kamath BM, Walters TD, Frost K, Carman N, Church PC, et al. New onset autoimmune hepatitis during anti-tumor necrosis factor-alpha treatment in children. J Pediatr. (2018) 194:128-35.e1. doi: 10.1016/j.jpeds.2017.10.071

77. Faustman DL. TNF, TNF inducers, and TNFR2 agonists: a new path to type 1 diabetes treatment. Diabetes Metab Res Rev. (2018) 34. doi: 10.1002/dmrr.2941

78. Webb GJ, Hirschfield GM, Krawitt EL, Gershwin ME. Cellular and molecular mechanisms of autoimmune hepatitis, Annu. Rev. Pathol. (2018) 13:247-92. doi: 10.1146/annurev-pathol-020117-043534

79. De Biasio MB, Periolo N, Avagnina A, García de Dávila MT, Ciocca $\mathrm{M}$, Goñi J., et al. Liver infiltrating mononuclear cells in children with type 1 autoimmune hepatitis. J Clin Pathol. (2006) 59:417-23. doi: $10.1136 /$ jcp.2005.028613

80. Wen L, Peakman M, Lobo-Yeo A, McFarlane BM, Mowat AP, Mieli-Vergani $\mathrm{G}$, et al. T-cell-directed hepatocyte damage in autoimmune chronic active hepatitis. Lancet. (1990) 336:1527-30. doi: 10.1016/0140-6736(90)93306-A

81. Bowen DG, Warren A, Davis T, Hoffmann MW, McCaughan GW, Fazekas de St Groth B., et al. Cytokine-dependent bystander hepatitis due to intrahepatic murine CD8 T-cell activation by bone marrow-derived cells. Gastroenterology. (2002) 123:1252-64. doi: 10.1053/gast.2002.36058

82. Vergani D, Mieli-Vergani G, Mondelli M, Portmann B, Eddleston AL. Immunoglobulin on the surface of isolated hepatocytes is associated with antibody-dependent cell-mediated cytotoxicity and liver damage. Liver. (1987) 7:307-5. doi: 10.1111/j.1600-0676.1987.tb00361.x

83. Hardtke-Wolenski M, Fischer K, Noyan F, Schlue J, Falk CS, Stahlhut $\mathrm{M}$, et al. Genetic predisposition and environmental danger signals initiate chronic autoimmune hepatitis driven by CD4+ T cells. Hepatology. (2013) 58:718-28. doi: 10.1002/hep.26380

84. Lohr HF, Schlaak JF, Lohse AW, Bocher WO, Arenz M, Gerken $\mathrm{G}$, et al. Autoreactive CD4+ LKM-specific and anticlonotypic Tcell responses in LKM-1 antibody-positive autoimmune hepatitis. Hepatology. (1996) 24:1416-21. doi: 10.1053/jhep.1996.v24.pm0008 938173

85. Ma Y, Bogdanos DP, Hussain MJ, Underhill J, Bansal S, Longhi MS, et al. Polyclonal T-cell responses to cytochrome P450IID6 are associated with disease activity in autoimmune hepatitis type 2. Gastroenterology. (2006) 130:868-82. doi: 10.1053/j.gastro.2005.12.020

86. Beland K, Marceau G, Labardy A, Bourbonnais S, Alvarez F. Depletion of B cells induces remission of autoimmune hepatitis in mice through reduced antigen presentation and help to T cells. Hepatology. (2015) 62:1511-23. doi: 10.1002/hep.27991

87. Liu X, Jiang X, Liu R, Wang L, Qian $\mathrm{T}$, Zheng $\mathrm{Y}$, et al. B cells expressing CD11b effectively inhibit CD4+ T-cell responses and ameliorate experimental autoimmune hepatitis in mice. Hepatology. (2015) 62:1563-75. doi: 10.1002/hep. 28001

88. Boross P, Leusen JH. Mechanisms of action of CD20 antibodies. Am J Cancer Res. (2012) 2:676-90.

89. Burak KW, Swain MG, Santodomingo-Garzon T, Lee SS, Urbanski SJ, Aspinall AI, et al. Rituximab for the treatment of patients with autoimmune hepatitis who are refractory or intolerant to standard therapy. Can J Gastroenterol. (2013) 27:273-80. doi: 10.1155/2013/ 512624
90. Al-Busafi SA, Michel RP, Deschenes M. Rituximab for refractory autoimmune hepatitis: a case report. Arab J Gastroenterol. (2013) 14:135-8. doi: 10.1016/j.ajg.2013.08.009

91. Rubin JN, Te HS. Refractory autoimmune hepatitis: beyond standard therapy. Dig Dis Sci. (2016) 61:1757-62. doi: 10.1007/s10620-015-4022-0

92. Evans JT, Shepard MM, Oates JC, Self SE, Reuben A. Rituximabresponsive cryoglobulinemic glomerulonephritis in a patient with autoimmune hepatitis. J Clin Gastroenterol. (2008) 42:862-3. doi: 10.1097/MCG.0b013e3180f60b7a

93. Barth E, Clawson J. A case of autoimmune hepatitis treated with rituximab. Case Rep Gastroenterol. (2010) 4:502-9. doi: 10.1159/000322693

94. Santos ES, Arosemena LR, Raez LE, O'Brien C, Regev A. Successful treatment of autoimmune hepatitis and idiopathic thrombocytopenic purpura with the monoclonal antibody, rituximab: case report and review of literature. Liver Int. (2006) 26:625-9. doi: 10.1111/j.1478-3231.2006.01262.x

95. D’Agostino D, Costaguta A, Álvarez F. Successful treatment of refractory autoimmune hepatitis with rituximab. Pediatrics. (2013) 132:e526-30. doi: 10.1542/peds.2011-1900

96. Carey EJ, Somaratne K, Rakela J. Successful rituximab therapy in refractory autoimmune hepatitis and Evans syndrome. Rev Med Chil. (2011) 139:14847. doi: 10.4067/S0034-98872011001100015

97. Liberal R, de Boer YS, Andrade RJ, Bouma G, Dalekos GN, Floreani A, et al. International Autoimmune Hepatitis Group (IAIHG). Expert clinical management of autoimmune hepatitis in the real world Aliment. Pharmacol Ther. (2017) 45:723-32. doi: 10.1111/apt.13907

98. Than NN, Schmidt D, Hodson J, Wawman R, Burak K, Botter M, et al. Rituximab treatment experience in patients with complicated type 1 autoimmune hepatitis in Europe and North America. J Hepatol. (2018) 68:S217-8. doi: 10.1016/S0168-8278(18)30652-4

99. Carson KR, Focosi D, Major EO, Petrini M, Richey EA, West DP, et al. Monoclonal antibody-associated progressive multifocal leucoencephalopathy in patients treated with rituximab, natalizumab, and efalizumab: a Review from the Research on Adverse Drug Events and Reports (RADAR). Project Lancet Oncol. (2009) 10:816-24. doi: 10.1016/S1470-2045(09)70161-5

100. Ferraccioli G, Gremese E. B cell activating factor (BAFF) and BAFF receptors: fakes and facts. Clin Exp Immunol. (2017) 190:291-2. doi: 10.1111/cei.13039

101. Harrington LE, Hatton RD, Mangan PR, Turner H, Murphy TL, Murphy $\mathrm{KM}$, et al. Interleukin 17-producing CD4 effector T cells develop via a lineage distinct from the T helper type 1 and 2 lineages. Nat Immunol. (2005) 6:1123-32. doi: 10.1038/ni1254

102. Korn T, Bettelli E, Oukka M, Kuchroo VK. IL-17 and Th17 Cells. Annu Rev Immunol. (2009) 27:485-517. doi: 10.1146/annurev.immunol.021908.132710

103. Bettelli E, Carrier Y, Gao W, Korn T, Strom TB, Oukka M, et al. Reciprocal developmental pathways for the generation of pathogenic effector TH17 and regulatory T cells. Nature. (2006) 441:235-8. doi: 10.1038/nature04753

104. Wolk K, Witte E, Witte K, Warszawska K, Sabat R. Biology of interleukin-22. Semin Immunopathol. (2010) 32:17-31. doi: 10.1007/s00281-009-0188-x

105. Dardalhon V, Korn T, Kuchroo VK, Anderson AC. Role of Th1 and Th17 cells in organ-specific autoimmunity. J Autoimmun. (2008) 31:252-6. doi: 10.1016/j.jaut.2008.04.017

106. Zhao L, Tang Y, You Z, Wang Q, Liang S, Han X, et al. Interleukin17 contributes to the pathogenesis of autoimmune hepatitis through inducing hepatic interleukin-6 expression. PLoS ONE. (2011) 6:e18909. doi: 10.1371/journal.pone.0018909

107. Lobo-Yeo A, Senaldi G, Portmann B, Mowat AP, Mieli-Vergani G, Vergani D. Class I and class II major histocompatibility complex antigen expression on hepatocytes: a study in children with liver disease. Hepatology. (1990) 12:224-32. doi: 10.1002/hep.1840120208

108. Zhang H, Bernuzzi F, Lleo A, Ma X, Invernizzi P. Therapeutic potential of IL-17-mediated signaling pathway in autoimmune liver diseases. Mediat Inflamm. (2015) 2015:436450. doi: 10.1155/2015/436450

109. Longhi MS, Liberal R, Holder B, Robson SC, Ma Y, Mieli-Vergani G, et al. Inhibition of interleukin-17 promotes differentiation of CD25(-) cells into stable $\mathrm{T}$ regulatory cells in patients with autoimmune hepatitis. Gastroenterology. (2012) 142:1526-35. doi: 10.1053/j.gastro.2012. 02.041 
110. McInnes IB, Mease PJ, Ritchlin CT, Rahman P, Gottlieb AB, Kirkham B. Secukinumab sustains improvement in signs and symptoms of psoriatic arthritis: 2 year results from the phase 3 FUTURE 2 study. Rheumatology. (2017) 56:1993-2003. doi: 10.1093/rheumatology/kex301

111. Strober BE, Germino R, Guana A, Greenberg JD, Litman HJ, Guo N, et al. US real-world effectiveness of secukinumab for the treatment of psoriasis: 6-month analysis from the Corrona Psoriasis Registry. J Dermatolog Treat. (2019) 29:1-9. doi: 10.1080/09546634.2019.1603361

112. Genovese MC, Durez P, Richards HB, Supronik J, Dokoupilova E, Mazurov V, et al. Efficacy and safety of secukinumab in patients with rheumatoid arthritis: a phase II, dose-finding, double-blind, randomised, placebo controlled study. Ann Rheum Dis. (2013) 72:863-9. doi: 10.1136/annrheumdis-2012-201601

113. Baeten D, Baraliakos X, Braun J, Sieper J, Emery P, van der Heijde D, et al. Anti-interleukin-17A monoclonal antibody secukinumab in treatment of ankylosing spondylitis: a randomised, double-blind, placebo-controlled trial. Lancet. (2013) 382:1705-13. doi: 10.1016/S0140-6736(13)61134-4

114. Dick AD, Tugal-Tutkun I, Foster S, Zierhut M, Melissa Liew SH, Bezlyak V, et al. Secukinumab in the treatment of noninfectious uveitis: results of three randomized, controlled clinical trials. Ophthalmology. (2013) 120:777-87. doi: 10.1016/j.ophtha.2012.09.040

115. Hueber W, Sands BE, Lewitzky S, Vandemeulebroecke M, Reinisch W, Higgins PD, et al. Secukinumab in Crohn's Disease Study Group. Secukinumab, a human anti-IL-17A monoclonal antibody, for moderate to severe Crohn's disease: unexpected results of a randomised, double-blind placebo-controlled trial. Gut. (2012) 61:1693-700. doi: 10.1136/gutjnl-2011-301668

116. Ritchlin C, Rahman P, Kavanaugh A, McInnes IB, Puig L, Li S, et al. PSUMMIT 2 Study Group. Efficacy and safety of the anti-IL-12/23 p40 monoclonal antibody, ustekinumab, in patients with active psoriatic arthritis despite conventional non-biological and biological anti-tumour necrosis factor therapy: 6-month and 1-year results of the phase 3, multicentre, double-blind, placebo-controlled, randomised PSUMMIT 2 trial. Ann Rheum Dis. (2014) 73:990-9. doi: 10.1136/annrheumdis-2013-204655

117. Sandborn WJ, Gasink C, Gao LL, Blank MA, Johanns J, Guzzo C, et al. CERTIFI Study Group. Ustekinumab induction and maintenance therapy in refractory Crohn's disease. N Engl J Med. (2012) 367:1519-28. doi: 10.1056/NEJMoa1203572

118. Zweegers J, Groenewoud JMM, van den Reek JMPA, Otero ME, van de Kerkhof PCM, Driessen RJB, et al. Comparison of the 1- and 5year effectiveness of adalimumab, etanercept and ustekinumab in patients with psoriasis in daily clinical practice: results from the prospective BioCAPTURE registry. Br J Dermatol. (2017) 176:1001-9. doi: 10.1111/bjd. 15023

119. Mirouse A, Barete S, Desbois AC, Comarmond C, Sène D, Domont F, et al. Long term outcome of ustekinumab therapy for Behçet's disease. Arthritis Rheumatol. (2019). doi: 10.1002/art.40912. [Epub ahead of print].

120. Segal BM, Constantinescu CS, Raychaudhuri A, Kim L, FidelusGort R, Kasper LH. Repeated subcutaneous injections of IL12/23 p40 neutralising antibody, ustekinumab, in patients with relapsingremitting multiple sclerosis: a phase II, double-blind, placebo-controlled, randomised, dose-ranging study. Lancet Neurol. (2008) 7:796-804. doi: 10.1016/S1474-4422(08)70173-X

121. Hirschfield GM, Gershwin ME, Strauss R, Mayo MJ, Levy C, Zou B, et al. Ustekinumab for patients with primary biliary cholangitis who have an inadequate response to ursodeoxycholic acid: a proof-of-concept study, Hepatology. (2016) 64:189-99. doi: 10.1002/hep.28359

122. Tonini A, Gualtieri B, Panduri S, Romanelli M, Chiricozzi A. A new class of biologic agents facing the therapeutic paradigm in psoriasis: anti-IL-23 agents. Expert Opin Biol Ther. (2018) 18:135-48. doi: 10.1080/14712598.2018.1398729

123. Shetty A, Hanson R, Korsten P, Shawagfeh M, Arami S, Volkov S, et al. Tocilizumab in the treatment of rheumatoid arthritis and beyond. Drug Des Devel Ther. (2014) 8:349-64. doi: 10.2147/DDDT.S41437

124. Frampton JE. Tocilizumab: a review of its use in the treatment of juvenile idiopathic arthritis. Pediatric Drugs. (2013) 15:515-31. doi: $10.1007 /$ s40272-013-0053-1
125. González-Gay MÁ, Pina T, Prieto-Peña D, Calderon-Goercke M, Gualillo O, Castañeda S. Treatment of giant cell arteritis. Biochem Pharmacol. (2019) 165:230-9. doi: 10.1016/j.bcp.2019.04.027

126. Schwartz DM, Kanno Y, Villarino A, Ward M, Gadina M, O’Shea JJ. JAK inhibition as a therapeutic strategy for immune and inflammatory diseases. Nat Rev Drug Discov. (2017) 16:843-62. doi: 10.1038/nrd.2017.201

127. Yang XO, Pappu BP, Nurieva R, Akimzhanov A, Kang HS, Chung Y, et al. $\mathrm{T}$ helper 17 lineage differentiation is programmed by orphan nuclear receptors ROR alpha and ROR gamma. Immunity. (2008) 28:29-39. doi: 10.1016/j.immuni.2007.11.016

128. Khan PM, El-Gendy Bel D, Kumar N, Garcia-Ordonez R, Lin L, Ruiz CH, et al. Small molecule amides as potent ROR- $\gamma$ selective modulators Bioorg. Med Chem Lett. (2013) 23:532-6. doi: 10.1016/j.bmcl.2012.11.025

129. Tang Q, Bluestone JA. The Foxp3+ regulatory T cell: a jack of all trades, master of regulation. Nat Immunol. (2008) 9:239-44. doi: 10.1038/ni1572

130. Josefowicz SZ, Lu LF, Rudensky AY. Regulatory T cells: mechanisms of differentiation and function. Annu Rev Immunol. (2012) 30:531-64. doi: 10.1146/annurev.immunol.25.022106.141623

131. Hori S, Nomura T, Sakaguchi S. Control of regulatory T cell development by the transcription factor Foxp3. Science. (2003) 299:1057-61. doi: 10.1126/science. 1079490

132. Karim M, Kingsley CI, Bushell AR, Sawitzki BS, Wood KJ. Alloantigeninduced CD25+ CD4+ regulatory T cells can develop in vivo from CD25CD4? precursors in a thymusin-dependent process. J Immunol. (2004) 172:923-8. doi: 10.4049/jimmunol.172.2.923

133. Fletcher JM, Lonergan R, Costelloe L, Kinsella K, Moran B, O'Farrelly C, et al. CD39+Foxp3+ regulatory T Cells suppress pathogenic Th17 cells and are impaired in multiple sclerosis. J Immunol. (2009) 183:7602-10. doi: 10.4049/jimmunol.0901881

134. O'Garra A, Vieira PL, Vieira P, Goldfeld AE. IL-10-producing and naturally occurring CD4+ Tregs: limiting collateral damage. J Clin Invest. (2004) 114:1372-8. doi: 10.1172/JCI200423215

135. Kobie JJ, Shah PR, Yang L, Rebhahn JA, Fowell DJ, Mosmann TR. $\mathrm{T}$ regulatory and primed uncommitted CD4 $\mathrm{T}$ cells express CD73, which suppresses effector CD4 T cells by converting 5'-adenosine monophosphate to adenosine. J Immunol. (2006) 177:6780-6. doi: 10.4049/jimmunol.177.10.6780

136. Liberal R, Grant CR, Holder BS, Ma Y, Mieli-Vergani G, Vergani D, et al. The impaired immune regulation of autoimmune hepatitis is linked to a defective galectin-9/tim-3 pathway. Hepatology. (2012) 56:677-86. doi: 10.1002/hep.25682

137. Okeke EB, Uzonna JE. The pivotal role of regulatory $\mathrm{T}$ cells in the regulation of innate immune cells. Front Immunol. (2019) 10:680. doi: 10.3389/fimmu.2019.00680

138. Zhao B, Chang L, Fu H, Sun G, Yang W. The Role of Autoimmune Regulator (AIRE) in Peripheral Tolerance. J Immunol Res. (2018) 2018:3930750. doi: 10.1155/2018/3930750

139. Van der Vliet HJ, Nieuwenhuis EE. IPEX as a result of mutations in FOXP3. Clin Dev Immunol. (2007) 2007:89017. doi: 10.1155/2007/89017

140. Wan YY, Flavell RA. Regulatory T-cell functions are subverted and converted owing to attenuated Foxp3 expression. Nature. (2007) 445:766-70. doi: 10.1038/nature05479

141. Piloni D, Morosini M, Magni S, Balderacchi A, Scudeller L, Cova E. Analysis of long term CD4+CD25highCD127- T-reg cells kinetics in peripheral blood of lung transplant recipients. BMC Pulm Med. (2017) 17:102. doi: 10.1186/s12890-017-0446-y

142. Longhi MS, Ma Y, Bogdanos DP, Cheeseman P, Mieli-Vergani G, Vergani D. Impairment of CD4(+)CD25(+) regulatory T-cells in autoimmune liver disease. J Hepatol. (2004) 41:31-7. doi: 10.1016/j.jhep.2004.03.008

143. Longhi MS, Hussain MJ, Mitry RR, Arora SK, Mieli-Vergani G, Vergani D, et al. Functional study of CD4+CD25+ regulatory T cells in health and autoimmune hepatitis. J Immunol. (2006) 176:4484-91. doi: 10.4049/jimmunol.176.7.4484

144. Ferri S, Longhi MS, De Molo C, Lalanne C, Muratori P, Granito A, et al. A multifaceted imbalance of $\mathrm{T}$ cells with regulatory function characterizes type 1 autoimmune hepatitis. Hepatology. (2010) 52:999-1007. doi: 10.1002/hep.23792 
145. Grant CR, Liberal R, Holder BS, Cardone J, Ma Y, Robson SC, et al. Dysfunctional CD39(POS) regulatory $\mathrm{T}$ cells and aberrant control of Thelper type 17 cells in autoimmune hepatitis. Hepatology. (2014) 59:1007-15. doi: 10.1002/hep. 26583

146. Liberal R, Grant CR, Holder BS, Cardone J, Martinez-Llordella M, Ma $\mathrm{Y}$, et al. In autoimmune hepatitis type 1 or the autoimmune hepatitissclerosing cholangitis variant defective regulatory $\mathrm{T}$-cell responsiveness to IL-2 results in low IL-10 production and impaired suppression. Hepatology. (2015) 62:863-75. doi: 10.1002/hep.27884

147. Peiseler M, Sebode M, Franke B, Wortmann F, Schwinge D, Quaas A, et al. FOXP3 + regulatory $\mathrm{T}$ cells in autoimmune hepatitis are fully functional and not reduced in frequency. J Hepatol. (2012) 57:125-32. doi: 10.1016/j.jhep.2012.02.029

148. Diestelhorst J, Junge N, Schlue J, Falk CS, Manns MP, Baumann U, et al. Pediatric autoimmune hepatitis shows a disproportionate decline of regulatory T cells in the liver and of IL-2 in the blood of patients undergoing therapy. PLoS ONE. (2017) 12:e0181107. doi: 10.1371/journal.pone.0181107

149. Jeffery HC, Braitch MK, Brown S, Oo YH. Clinical potential of regulatory $\mathrm{T}$ cell therapy in liver diseases: an overview and current perspectives. Front Immunol. (2016) 7:334. doi: 10.3389/fimmu.2016.00334

150. Lapierre P, Beland K, Yang R, Alvarez F. Adoptive transfer of ex vivo expanded regulatory $\mathrm{T}$ cells in an autoimmune hepatitis murine model restores peripheral tolerance. Hepatology. (2013) 57:217-27. doi: 10.1002/hep.26023

151. Oo YH, Weston CJ, Lalor PF, Curbishley SM, Withers DR, Reynolds GM, et al. Distinct roles for CCR4 and CXCR3 in the recruitment and positioning of regulatory $\mathrm{T}$ cells in the inflamed human liver. J Immunol. (2010) 184:2886-98. doi: 10.4049/jimmunol.0901216

152. Todo S, Yamashita K, Goto R, Zaitsu M, Nagatsu A, Oura T, et al. A pilot study of operational tolerance with a regulatory $\mathrm{T}$ cell-based cell therapy in living donor liver transplantation. Hepatology. (2016) 64:632-43. doi: 10.1002/hep.28459

153. Trzonkowski P, Bieniaszewska M, Juścinska J, Dobyszuk A, Krzystyniak A, Marek N, et al. First-in-man clinical results of the treatment of patients with graft versus host disease with human ex vivo expanded CD4+CD25+CD127 - T regulatory cells. Clin Immunol. (2009) 133:22-6. doi: 10.1016/j.clim.2009.06.001

154. Di Ianni M, Falzetti F, Carotti A, Terenzi A, Castellino F, Bonifacio E, et al. Tregs prevent GVHD and promote immune reconstitution in HLA-haploidentical transplantation. Blood. (2011) 117:3921-8. doi: 10.1182/blood-2010-10-311894

155. Brunstein CG, Miller JS, Cao Q, McKenna DH, Hippen KL, Curtsinger J, et al. Infusion of ex vivo expanded T regulatory cells in adults transplanted with umbilical cord blood: safety profile and detection kinetics. Blood. (2011) 117:1061-70. doi: 10.1182/blood-2010-07-293795

156. Marek-Trzonkowska N, Mysliwiec M, Dobyszuk A, Grabowska M, Techmanska I, Juscinska J, et al. Administration of CD4+CD25highCD127 - regulatory $\mathrm{T}$ cells preserves beta-cell function in type 1 diabetes in children. Diabetes Care. (2012) 35:1817-20. doi: 10.2337/dc12-0038

157. Bluestone JA, Buckner JH, Fitch M, Gitelman SE, Gupta S, Hellerstein MK, et al. Type 1 diabetes immunotherapy using polyclonal regulatory T cells. Sci Transl Med. (2015) 7:315ra189. doi: 10.1126/scitranslmed.aad4134

158. Tang Q, Henriksen KJ, Bi M, Finger EB, Szot G, Ye J, et al. In vitro-expanded antigen-specific regulatory $\mathrm{T}$ cells suppress autoimmune diabetes. J Exp Med. (2004) 199:1455-65. doi: 10.1084/jem.20040139

159. Tarbell KV, Yamazaki S, Olson K, Toy P, Steinman RM. CD25+ CD4+ $\mathrm{T}$ cells, expanded with dendritic cells presenting a single autoantigenic peptide, suppress autoimmune diabetes. J Exp Med. (2004) 199:1467-77. doi: 10.1084/jem.20040180

160. Brusko TM, Koya RC, Zhu S, Lee MR, Putnam AL, McClymont SA, et al. Human antigen-specific regulatory $\mathrm{T}$ cells generated by $\mathrm{T}$ cell receptor gene transfer. PLoS ONE. (2010) 5:e11726. doi: 10.1371/journal.pone.0011726

161. Noyan F, Lee YS, Zimmermann K, Hardtke-Wolenski M, Taubert R, Warnecke $G$, et al. Isolation of human antigen-specific regulatory $\mathrm{T}$ cells with high suppressive function. Eur J Immunol. (2014) 44:2592-602. doi: 10.1002/eji.201344381

162. Noyan F, Lee YS, Hardtke-Wolenski M, Knoefel AK, Taubert R, Baron $\mathrm{U}$, et al. Donor-specific regulatory $\mathrm{T}$ cells generated on donor $\mathrm{B}$ cells are superior to CD4+CD25high cells in controlling alloimmune responses in human-ized mice. Transplant Proc. (2013) 45:1832-7. doi: 10.1016/j.transproceed.2013.01.073

163. Chera,ï M, Hamel Y, Baillou C, Touil S, Guillot-Delost M, Charlotte F, et al. Generation of human alloantigen-specific regulatory $\mathrm{T}$ cells under good manufacturing practice-compliant conditions for cell therapy. Cell Transplant. (2015) 24:2527-40. doi: 10.3727/096368914X683566

164. June CH, O’Connor RS, Kawalekar OU, Ghassemi S, Milone MC. CAR T cell immunotherapy for human cancer. Science. (2018) 359:1361-65. doi: 10.1126/science.aar6711

165. MacDonald KG, Hoeppli RE, Huang Q, Gillies J, Luciani DS, Orban PC, et al. Alloantigen-specific regulatory $\mathrm{T}$ cells generated with a chimeric antigen receptor. J Clin Invest. (2016) 126:1413-24. doi: 10.1172/JCI82771

166. Boardman DA, Philippeos C, Fruhwirth GO, Ibrahim MA, Hannen RF, Cooper D, et al. Expression of a chimeric antigen receptor specific for donor HLA class I enhances the potency of human regulatory $\mathrm{T}$ cells in preventing human skin transplant rejection. Am J Transplant. (2017) 17:931-43. doi: 10.1111/ajt.14185

167. Longhi MS, Hussain MJ, Kwok WW, Mieli-Vergani G, Ma Y, Vergani D. Autoantigen-specific regulatory $\mathrm{T}$ cells, a potential tool for immunetolerance reconstitution in type-2 autoimmune hepatitis. Hepatology. (2011) 53:536-47. doi: 10.1002/hep.24039

168. Liao W, Lin JX, Leonard WJ. Interleukin-2 at the crossroads of effector responses, tolerance, and immunotherapy. Immunity. (2013) 38:13-25. doi: 10.1016/j.immuni.2013.01.004

169. Wakabayashi K, Lian ZX, Moritoki Y, Lan RY, Tsuneyama K, Chuang YH, et al. IL-2 receptor alpha(-/-) mice and the development of primary biliary cirrhosis. Hepatology. (2006) 44:1240e-49. doi: 10.1002/hep.21385

170. Webb GJ, Hirschfield GM. Using GWAS to identify genetic predisposition in hepatic autoimmunity. J Autoimmun. (2016) 66:25-39. doi: 10.1016/j.jaut.2015.08.016

171. Bo X, Broome U, Remberger M, Sumitran-Holgersson S. Tumour necrosis factor alpha impairs function of liver derived $\mathrm{T}$ lymphocytes and natural killer cells in patients with primary sclerosing cholangitis. Gut. (2001) 49:131-41. doi: 10.1136/gut.49.1.131

172. Czaja AJ, Sievers C, Zein NN. Nature and behavior of serum cytokines in type 1 autoimmune hepatitis. Dig Dis Sci. (2000) 45:1028-35. doi: 10.1023/A:1005506031717

173. Diestelhorst J, Junge N, Jonigk D, Schlue J, Falk CS, Manns MP, et al. Baseline IL-2 and the AIH score can predict the response to standard therapy in paediatric autoimmune hepatitis. Sci Rep. (2018) 8:419. doi: 10.1038/s41598-017-18818-5

174. Hartemann A, Bensimon G, Payan CA, Jacqueminet S, Bourron O, Nicolas $\mathrm{N}$, et al. Low-dose interleukin 2 in patients with type 1 diabetes: a phase 1/2 randomised, double-blind, placebo-controlled trial. Lancet Diabetes Endocrinol. (2013) 1:295-305. doi: 10.1016/S2213-8587(13)70113-X

175. Von Spee-Mayer C, Siegert EE, Abdirama D, Rose A, Klaus A, Alexander $\mathrm{T}$, et al. Low-dose interleukin-2 selectively corrects regulatory $\mathrm{T}$ cell defects in patients with systemic lupus erythematosus, Ann. Rheum Dis. (2016) 75:1407-15. doi: 10.1136/annrheumdis-2015-207776

176. Lim TY, Martinez-Llordella M, Kodela E, Gray E, Heneghan MA, SanchezFueyo A. Low dose interleukin-2 for refractory autoimmune hepatitis. Hepatology. (2018) 68:1649-52. doi: 10.1002/hep.30059

177. Long SA, Rieck M, Sanda S, Bollyky JB, Samuels PL, Goland R. Rapamycin/IL-2 combination therapy in patients with type 1 diabetes augments Tregs yet transiently impairs beta-cell function. Diabetes. (2012) 61:2340-8. doi: 10.2337/db12-0049

178. Trotta E, Bessette PH, Silveria SL, Ely LK, Jude KM, Le DT, et al. A human anti-IL-2 antibody that potentiates regulatory $\mathrm{T}$ cells by a structure-based mechanism. Nat Med. (2018) 24:1005-14. doi: 10.1038/s41591-018-0070-2

179. Uccelli A, Moretta L, Pistoia V. Mesenchymal stem cells in health and disease. Nat Rev Immunol. (2008) 8:726-36. doi: 10.1038/nri2395

180. Arsenijevic A, Harrell CR, Fellabaum C, Volarevic V. Mesenchymal stem cells as new therapeutic agents for the treatment of primary biliary cholangitis. Anal Cell Pathol. (2017) 2017:7492836. doi: 10.1155/2017/7492836

181. Wang L, Li J, Liu H, Li Y, Fu J, Sun Y, et al. Pilot study of umbilical cord derived mesenchymal stem cell transfusion in patients with primary 
biliary cirrhosis. J Gastroenterol Hepatol. (2013) 28:85-92. doi: 10.1111/jgh. 12029

182. Cantarelli C, Angeletti A, Cravedi P. Erythropoietin, a multifaceted protein with innate and adaptive immune modulatory activity. Am J Transplant. (2019) 19: 2407-14. doi: 10.1111/ajt.15369

183. Lozupone CA, Stombaugh JI, Gordon JI, Jansson JK, Knight R. Diversity, stability and resilience of the human gut microbiota. Nature. (2012) 489:22030. doi: 10.1038/nature11550

184. Henao-Mejia J, Elinav E, Thaiss CA, Licona-Limon P, Flavell RA. Role of the intestinal microbiome in liver disease. J Autoimmun. (2013) 46:66-73. doi: 10.1016/j.jaut.2013.07.001

185. Strowig T, Henao-Mejia J, Elinav E, Flavell R. Inflammasomes in health and disease. Nature. (2012) 481:278-86. doi: 10.1038/nature10759

186. Wen L, Ley RE, Volchkov PY, Stranges PB, Avanesyan L, Stonebraker AC, et al. Innate immunity and intestinal microbiota in the development of Type 1 diabetes. Nature. (2008) 455:1109-13. doi: 10.1038/nature07336

187. Frank DN, Robertson CE, Hamm CM, Kpadeh Z, Zhang T, Chen H, et al. Disease phenotype and genotype are associated with shifts in intestinalassociated microbiota in inflammatory bowel diseases. Inflamm Bowel Dis. (2011) 17:179-84. doi: 10.1002/ibd.21339

188. Vaahtovuo J, Munukka E, Korkeamaki M, Luukkainen R, Toivanen P. Fecal microbiota in early rheumatoid arthritis. J Rheumatol. (2008) 35:1500-5.

189. Tabibian JH, O’Hara SP, Trussoni CE, Tietz PS, Splinter PL, Mounajjed T, et al. Absence of the intestinal microbiota exacerbates hepatobiliary disease in a murine model of primary sclerosing cholangitis. Hepatology. (2016) 63:185-96. doi: 10.1002/hep.27927

190. Abe K, Takahashi A, Fujita M, Imaizumi H, Hayashi M, Okai K, et al. Dysbiosis of oral microbiota and its association with salivary immunological biomarkers in autoimmune liver disease. PLoS ONE. (2018) 13:e0198757. doi: 10.1371/journal.pone.0198757

191. Yuksel M, Wang Y, Tai N, Peng J, Guo J, Beland K, et al. A novel "humanized mouse" model for autoimmune hepatitis and the association of gut microbiota with liver inflammation. Hepatology. (2015) 62:1536-50. doi: 10.1002/hep. 27998

192. Eksteen B, Grant AJ, Miles A, Curbishley SM, Lalor PF, Hübscher SG, et al. Hepatic endothelial CCL25 mediates the recruitment of CCR9+ gut-homing lymphocytes to the liver in primary sclerosing cholangitis. J Exp Med. (2004) 200:1511-7. doi: 10.1084/jem.20041035

193. Markle JG, Frank DN, Adeli K, von Bergen M, Danska JS. Microbiome manipulation modifies sex-specific risk for autoimmunity. Gut Microbes. (2014) 5:485-93. doi: 10.4161/gmic.29795

194. Hsu MC, Liu SH, Wang CW, Hu NY, Wu ESC, Shih YC, et al. JKB-122 is effective, alone or in combination with prednisolone in Con A-induced hepatitis. Eur J Pharmacol. (2017) 812:113-20. doi: 10.1016/j.ejphar.2017.07.012

195. Relman DA. Microbiota: a high-pressure situation for bacteria. Nature. (2017) 551:571-2. doi: 10.1038/nature24760

196. Kleinewietfeld M, Manzel A, Titze J, Kvakan H, Yosef N, Linker RA, et al. Sodium chloride drives autoimmune disease by the induction of pathogenic TH17cells. Nature. (2013) 496:518-22. doi: 10.1038/nature11868

197. Smith PM, Howitt MR, Panikov N, Michaud M, Gallini CA, Bohlooly $\mathrm{YM}$, et al. The microbial metabolites, short-chain fatty acids, regulate colonic Tregs cell homeostasis. Science. (2013) 341:569-73. doi: 10.1126/science.1241165

198. Hu ED, Chen DZ, Wu JL, Lu FB, Chen L, Zheng MH, et al. High fiber dietary and sodium butyrate attenuate experimental autoimmune hepatitis through regulation of immune regulatory cells and intestinal barrier. Cell Immunol. (2018) 328:24-32. doi: 10.1016/j.cellimm.2018.03.003

199. Lin R, Zhou L, Zhang J, Wang B. Abnormal intestinal permeability and microbiota in patients with autoimmune hepatitis. Int J Clin Exp Pathol. (2015) 8:5153-60.

Conflict of Interest Statement: The authors declare that the research was conducted in the absence of any commercial or financial relationships that could be construed as a potential conflict of interest.

Copyright (c) 2019 Sciveres, Nastasio and Maggiore. This is an open-access article distributed under the terms of the Creative Commons Attribution License (CC BY). The use, distribution or reproduction in other forums is permitted, provided the original author(s) and the copyright owner(s) are credited and that the original publication in this journal is cited, in accordance with accepted academic practice. No use, distribution or reproduction is permitted which does not comply with these terms. 